\title{
The Medieval Chinese Gäthā and Its Relationship to Poetry
}

\author{
Thomas J. Mazanec \\ (University of California, Santa Barbara)
}

\begin{abstract}
This paper investigates the shifting definitions of the term gātha (Ch. ji) over an 8oo-year period, from the earliest sütra translations into Chinese until the mid-tenth century. Although the term originally referred to the verse sections of scriptures, gāthās soon began to circulate separately, used in ritual, contemplative, and pedagogical practices. By the late sixth century, it began to mean something like "Buddhist verse." Over the course of the Tang, gāthās came to take on the formal features of poetry, eventually becoming all but indistinguishable from elite verse. However, the word $g \bar{a} t h \bar{a}$ was always seen as something inferior to real poetry, and, by the late Tang, we find poet-monks belittling other monks' didactic verses so as to distinguish their own work and avoid the taint of the word $g \bar{a} t h \bar{a}$.
\end{abstract}

\footnotetext{
* Parts of this essay were presented at the inaugural Stanford-Berkeley Graduate Student Conference on Pre-modern Chinese Humanities in April 2014 and at the "Scripture as Literature" panel organized by Paul Rouzer for the 131st MLA Annual Convention in January 2016. I would like to thank the organizers and participants at those events for the opportunity to present and receive feedback. Stephen F. Teiser, James Benn, and especially T'oung Pao's anonymous reviewers have also offered many valuable comments that I have incorporated into this paper, for which I am grateful.

The following abbreviations are used in this essay:

QTS Quan Tang shi 全唐詩. Comp. Peng Dingqiu 彭定求 (1676-1719) et al. Beijing: Zhonghua shuju, 1960.

QTSBB Quan Tang shibubian 全唐詩補編. Comp. Chen Shangjun 陳尚君. Beijing: Zhonghua shuju, 1992.

QTW Quan Tang wen 全唐文. Comp. Dong Hao 董浩 et al. Beijing: Zhonghua shuju, 1983.

T Taishō shinshū daizōkyō 大正新脩大藏經. Ed. Takakusu Junjirō 高楠順次郎 et al. Tōkyō: Taishō Issaikyō Kankōkai, 1924-1935.

Z Dai Nihon zokuzōkyō 大日本續藏經. Ed. Maeda Eun 前田慧雲 and Nakano Tatsue 中野達慧. Kyōto: Zōkyō Shōin, 1905-1912.
} 


\section{Résumé}

Cet article explore l'évolution du sens du terme gāthā (ch. ji) sur une période s'étendant sur plus de huit cent ans, depuis les premières traductions des sūtra en chinois jusqu'au milieu du dixième siècle. Bien que ce terme désignât à l'origine les parties rimées des textes sacrés bouddhiques, les gāthās très tôt commencèrent à circuler indépendamment et à être employées dans les pratiques rituelles, contemplatives et pédagogiques. Vers la fin du sixième siècle, il devint synonyme de « poésie bouddhique ». Au cours de la dynastie des Tang, les gāthās adoptèrent les règles formelles de la poésie, si bien qu'ils devinrent quasiment identiques aux autres formes d'expression poétique des élites. Le mot gāthā cependant continua à évoquer un style inférieur à celui de la «vraie » poésie, et à la fin des Tang des moines-poètes moquèrent les vers didactiques composés par d'autres moines dans le but de distinguer leur propres compositions et de se démarquer des connotations peu flatteuses du terme $g a \bar{t} h \bar{a}$.

\section{Keywords}

Buddhism, poetry, verse, gāthā, Late Tang

$$
\begin{array}{ll}
\text { 我詩也是詩 } & \text { My poetry is also poetry, } \\
\text { 有人喚作偈 } & \text { Though some call them gāthās. } \\
\text { 詩偈總一般 } & \text { Poetry and gāthās are the same: } \\
\text { 讀時須子細 } & \text { Be careful when you read them. } \\
& \text { - Shide 拾得 }{ }^{1}
\end{array}
$$

The Chinese word shi 詩 overlaps, but is not coterminous, with the English concept of "poetry." Looking at their origins, the differences are stark. The English "poetry," as is well known, comes from the Greek verb poieō meaning "to make," and thus most basically means "a work" or "something created" - a notion which underlines its artifice. Early literary thought expresses concern over the problem of mimesis, or the representation of reality, and thus over questions of truth or falsity. ${ }^{2}$ The Chinese shi, on the other hand, in the early period designated a textual

\footnotetext{
1) Hanshan shizhu fu Shide shizhu 寒山詩注附拾得詩注, ed. and annot. Xiang Chu 項楚 (Beijing: Zhonghua shuju, 2000), 844-45; QTS 807.9104.

2) Cf. the famous passages on mimesis in Plato's Republic, Book 10, and in Aristotle's Poetics, $1447 \mathrm{~b}-48 \mathrm{~b}$. I am, of course, oversimplifying for rhetorical purposes here. Verbal art was not always tied to the idea of "making" and a "maker." On the development of "poetry" as its own object of study in fifth-century BCE Greece (distinct from "song"), see Andrew Ford, The Origins of Criticism: Literary Culture and Poetic Theory in Classical Greece (Princeton: Princeton Univ. Press, 2009), 131-57.
} 
corpus of verses held in high esteem by the people of the Zhou dynasty (1046-256 BCE) and eventually canonized as the Book of Odes (Shijing 詩經). As early literary-critical sources tell us, one fundamental assumption about the Odes and the shi which descended therefrom is their expressive purpose. That is, growing out of lyric rather than drama, the main theme of this discourse is authenticity rather than realism. ${ }^{3}$

But for all their differences, shi and poetry both are markers of prestige. They are labels given only to those literary compositions deemed worthy of the term. In modern English usage, we apply the word "poetry" to works of art in other media when they seem to surpass the limits of those media and achieve a kind of aesthetic or expressive transcendence (such as when we call Terrence Malick's films "poetry" or "poetic"). All real poetry is assumed to at least attempt, if not reach, such lofty targets. Donald Hall's essay "Poetry and Ambition" defined "true ambition in a poet" as being "to make words that live forever." More recently, Ben Lerner has proposed that the reason poetry is so widely hated in the contemporary U.S. is because "poetry arises from the desire to get beyond the finite and the historical — the human world of violence and difference - and to reach the transcendent or divine," a necessarily "impossible demand." ${ }^{5}$ The outlandishly lofty expectations we place on poetry reveal our understanding of the concept as prescriptive, that it is circumscribed, admitting of only the greatest literary works.

$S h i$, in the medieval period (220-960 CE), had a slightly different kind of value judgment embedded in it, as the term contained some vestigial

3) On mimetic-expressive vs. affective-expressive assumptions about poetry in the GrecoRoman and Chinese traditions, respectively, see Miner, Comparative Poetics: An Intercultural Essay on Theories of Literature (Princeton: Princeton Univ. Press, 1990), esp. 18-31; and Stephen Owen, Traditional Chinese Poetry and Poetics: Omen of the World (Madison: Univ. of Wisconsin Press, 1985). For some early texts of Chinese poetics describing their function of manifesting humans' internal responses to external events and consequent concerns over the authenticity of poetic expression, see Stephen Owen, Readings in Chinese Literary Thought (Cambridge, Mass.: Council on East Asian Studies, Harvard Univ., 1992), 19-56. In order to avoid a simplistic East-West binary, it is worthwhile to keep in mind the etymology of Sanskrit kāvya from $\sqrt{ } k \bar{u}$, meaning "to sound, to cry out" and $k \bar{a} v y a$ 's other early meaning of "praiseworthy." For more on kārya and classical Sanskrit notions of literariness, see Sheldon Pollock, "Sanskrit Literary Culture from the Inside Out," in Literary Cultures in History: Reconstructions from South Asia, ed. Pollock (Berkeley: Univ. of California Press, 2003), 39-130.

4) Donald Hall, "Poetry and Ambition," The Kenyon Review, new ser. 5.4 (1983): 92.

5) Ben Lerner, The Hatred of Poetry (New York: Farrar, Straus and Giroux, 2016), 7-8, 13. 
authority of the Book of Odes. This is clearly seen in the late Han and Three Kingdoms periods, when the line between "Ode" and "poem" was still blurry. ${ }^{6}$ But even as the two meanings grew more distinct, shi in its more narrow sense (sometimes translated as "lyric poetry" or "classical poetry") was regarded as an extension of the Odes, with all the glory tied to that ancient classic. Xiao Tong 蕭統 (501-531), editor of the Wenxuan 文選, opened the shi section of his influential anthology with a poetic sequence directly tied to the Odes itself, Shu Xi's 束晳 (263-302 CE) six "Buwangshi" 補亡詩 ("Filling out the Lost Odes"). ${ }^{7}$ Likewise, Jiaoran 晈然 (720?-797?) began the preface to his Poetic Paradigms (Shishi) 詩式 by stating, "Poetry (shi) is the finest fruit of all wonder, the purest flowering of the Six Classics: though not the product of the sages, in its wonder it is equal to the sages” 夫詩者, 眾妙之華實, 六經之菁英。 雖非聖功, 妙均於聖. ${ }^{8}$ The organic metaphor Jiaoran uses-fruit and flower-emphasizes the continuity between shi-poetry and the Odes: the former grows out of the latter. The passage's key term miao 妙, translated as "wonder," refers to the subtle sublimities which display a poet's skill and offer an insight into the nature of the cosmos. With such a lofty function attributed to $s h i$, it is clear that the term is evaluative, that not everything can be poetry. Indeed, we can read the entire genre of "poetry standards" (shige 詩格) which flourished in the late Tang dynasty as prescriptive, providing guidelines for what should or should not be considered poetry. ${ }^{9}$

6) Cf. Zeb Raft, "The Beginning of Literati Poetry: Four Poems from First-century вСE China," T'oung Pao 96 (2010): 74-124.

7) On Xiao Tong's deliberate arrangement of the Wenxuan's sections to begin with the most orthodox forms, see David R. Knechtges, "Culling the Weeds and Selecting Prime Blossoms: The Anthology in Early Medieval China," in Culture and Power in the Reconstitution of the Chinese Realm, ed. Scott Pearce, Audrey Spiro, and Patricia Ebrey (Cambridge, Mass.: Harvard Univ. Asia Center, 2001), 224-25. On the "Buwangshi," see Zhang Baosan 張寶三, "Shu Xi 'Buwangshi' lunkao” 束晳補亡詩論考, in Diyijie jingxue xueshu taolunhui wenji chouyinben 第一屆經學學術討論會文集抽印本, ed. Guoli Taiwan Shifan Daxue guowenxi 國立 臺灣師範大學國文系 (Taipei: Wenshizhe chubanshe, 1994), 131-86.

8) Shishi jiaozhu 詩式校注, ed. Li Zhuangying 李壯鷹 (Beijing: Renmin wenxue chubanshe, 2003), 1; Zhang Bowei 張伯偉, ed., Quan Tang Wudai shige huikao 全唐五代詩格彙考 (Nanjing: Fenghuang chubanshe, 2002), 222. For more on Jiaoran's poetics, see Nicholas Morrow Williams, "The Taste of the Ocean: Jiaoran's Theory of Poetry," Tang Studies 31 (2013): 1-27.

9) Surprisingly, the "poetry standards," which are essentially manuals for the composition of poetry, are rarely consulted in the modern study of Tang verse. The standard collection of these works is Zhang Bowei, Quan Tang Wudai shige huikao (see n.9). For more on these 
Thus shi, like poetry, is more than just a descriptive term. It conveys cultural prestige, respectability. When something is called "poetry," it means that it is part of an elite discourse, that it is something worthy of your time and serious consideration. The converse of this elevation is the act of exclusion. What is not considered poetry is deemed unworthy of sustained reflection. Non-poetry has no mystery. It is utilitarian. Like the newspaper, it serves a temporary purpose, to be discarded by the next morning. To put it in the terms of Zhuangzi 莊子, one "grasps the meaning, then discards the words" 得意而忘言. ${ }^{10}$ Non-poetry is also mechanical, lacking deep thought. This is what Truman Capote meant when he dismissed Jack Kerouac by saying, "That's not writing; that's typing."11 Not all linguistic acts are poetry (or "writing" or "literature"); the term is usually reserved for those imbued with a certain kind of beauty, or meaning, or intention. Poetry, in the end, is what the cultural gatekeepers call poetry. ${ }^{12}$

In medieval China, the gātha falls directly on this fault line between poetry and non-poetry. Known in Chinese by the character $j i$ 偈 (and a variety of other words, discussed below), this term came to signify many things over the course of 800 years, from the first translations of

manuals, see Yugen Wang, "Shige: The Popular Poetics of Regulated Verse," T'ang Studies 22 (2004): 81-125; Charles Hartman, "The Yinchuang zalu 吟窗亲隹錄, Miscellaneous Notes from the Singing Window: A Song Dynasty Primer of Poetic Composition," in Recarving the Dragon: Understanding Chinese Poetics (Prague: Karolinum Press, 2003), 205-38; and Hartman,

"Du Fu in the Poetry Standards (Shige 詩格) and the Origins of the Earliest Du Fu Commentary," T'ang Studies 28 (2010): 61-76. I fundamentally disagree with the assumptions of Wang, Hartman, and Ronald Egan that the genre is inherently "popular" and aimed at the "semiliterati" composed of female and monastic poets (Hartman, "The Yinchuang zalu," 206; and Egan, The Problem of Beauty: Aesthetic Thought and Pursuits in Northern Song Dynasty China [Cambridge, Mass.: Harvard Univ. Asia Center, 2006], 78). Many were composed by the major poets of the late ninth and tenth centuries who are only considered minor because of the general disparagement of this time period in literary history.

10) Zhuangzijishi 莊子集釋, ed. Guo Qingfan 郭慶藩 (1844-1896) (Beijing: Zhonghua shuju, 1961), 26.944 .

11) Like many quotations from famous wits, Capote's remark was uttered on several occasions with multiple variations. The origin appears to be a January 1959 episode of the talk show "Open End," in which Capote disagreed with Norman Mailer's high praise of the Beat Generation writers. For an early print report of Capote's bon mot, see Janet Winn, "Capote, Mailer, and Miss Parker," The New Republic 140.6 (Feb. 9, 1959): 27.

12) This same exclusionary function is conspicuous in the use of the term kärya, too (see Pollock, "Sanskrit Literary Culture," 64). Cf. Stephen Owen, "Poetry," in The Princeton Encyclopedia of Poetry and Poetics, 4 th ed., ed. Roland Greene and Stephen Cushman (Princeton: Princeton Univ. Press, 2012), 1068. 
Buddhist scriptures in the late second century to the end of the medieval period in the mid-tenth century. ${ }^{13}$ To give a crude, preliminary definition which we will soon complicate, $g \bar{a} t h \bar{a}$ meant "Buddhist verse" in China. ${ }^{14}$ But the problem is thornier than this glib definition lets on. Though gātha originally signified something contained in translated scriptures, it soon took on a life of its own, and, as we shall see, the more closely it came to resemble poetry, the more it became a term of disparagement. By the late Tang (618-907) and Five Dynasties (907-96o) period, we even find poet-monks distancing themselves from this term. It is the purpose of this paper to chart the shifting definitions of the term gātha and to ask who is using this label and why. That is, what is at stake when a literatus, monk, or translator calls something a gāthā rather than a shi? In order to answer this question, we will look at some of the different texts called $g \bar{a} t h \bar{a}$ s and the discourse surrounding them, beginning with the earliest Chinese translations of Buddhist scriptures, continuing to collections of $g \bar{a} t h \bar{a}$ in the Six Dynasties (220-589 CE) period, to vernacular Buddhist verse in the Sui $(589-607)$ and early Tang, to the dharma-transmission gāthās of the eighth and ninth centuries, and concluding with the practices of literati and monks in the late ninth and early tenth century. This survey ${ }^{15}$ will show that gātha gradually became a contested term, eventually exiled from the realm of poetry.

\footnotetext{
13) I am selecting 940 as my end point because that that is when Qiji 齊已, a poet-monk who offered a history of the gāthā, passed away. Moreover, the term gātha began to stabilize around several definitions in the eleventh century, partly due to the influence of verses found in the growing Chan literature of encounter dialogues. To fully explain all of these changes is beyond the scope of the present essay. The interested reader may wish to consult two recent dissertations: Christopher Byrne, "Poetics of Silence: Hongzhi Zhengjue (10911157 ) and the Practice of Poetry in Song Dynasty Chan Yulu" (Ph.D. diss., McGill Univ., 2015), and Jason Protass, "Buddhist Monks and Chinese Poems: Song Dynasty Monastic Literary Culture" (Ph.D. diss., Stanford Univ., 2016).

14) Zhi Qian 支謙 (mid-third cent.), for example, writes in his "Preface to the Dharma-line Sūtra [Dhammapada]”法句經序: “Gāthā is sūtra-language meaning 'poem or hymn"” 偈者 經語, 猶詩頌也, Quan Sanguo wen 全三國文 75.12a (p. 1458b), in Yan Kejun 嚴可均 [1762-1843], comp., Quan shanggu sandai Qin Han Sanguo Liuchao wen 全上古三代秦漢三 國六朝文 [Beijing: Zhonghua shuju, 1991]; all references hereafter to "Complete" dynastic collections of prose from early times through the Six Dynasties are to this edition).

15) I am not attempting here a comprehensive study of Chinese gāthās, much less Chinese Buddhist verse. For basic orientations to Chinese Buddhist verse in Western languages, see, e.g., the introduction to Charles Egan's Clouds Thick, Whereabouts Unknown: Poems by Zen Monks of China (New York: Columbia Univ. Press, 2010), 2-55; the subsection on "Poetry" in François Martin, "Buddhism and Literature," in Early Chinese Religion, Part 2: The Period of
} 


\section{The Gāthà in Translation}

In Vedic Sanskrit, the term gātha simply means "song," from the root $g \bar{a}(y)$ - meaning "sing."16 In early Indian literary history, the term was most often used to refer to single-stanza verses, usually written in a kind of Prākrit instead of Sanskrit. The earliest anthology of such independent gāthās, the Gāhāsattasaī (Skt. Gāthāsaptaśatī, Eng. "Seven-hundred songs"), is said to have been compiled by King Hāla of the Sātavāhana, who reigned during the middle of the first century CE. ${ }^{17}$ This anthology seems "to have provided the most allure and sense of

Division (220-589 CE), ed. John Lagerwey and Lü Pengzhi (Leiden: Brill, 2009), 929-62; T. H. Barrett, "Poetry: China (Until the Song Period)," in Brill's Encyclopedia of Buddhism, ed. Jonathan Silk (Leiden: Brill, 2015), 1: 541-546; parts of Paul Rouzer, On Cold Mountain: A Buddhist Reading of the Hanshan Poems (Seattle: Univ. of Washington Press, 2015), esp. 51-65; Richard Robinson, Chinese Buddhist Verse (London: J. Murray, 1954); and Paul Demiéville, "Tchan et poesie I" and "Tchan et poesie II" in Choix d'études sinologiques (1921-1970) (Leiden: Brill, 1973), 274-87 and 322-29, respectively. More extensive studies of the topic exist in Chinese and Japanese, such as Fujiyoshi Masumi 藤善真澄, “Tōdai bunjin no shūkyōkan” 唐代文人 の宗教観, Rekishi kyūoiku 歴史教育 17.3 (1969): 28-35; Tsuda Sūokichi 津田左右吉, “Tōshi ni arawate iru Bukkyō to Dōkyō” 唐詩にあらはている仏教と道教, Tōyō shisō kenkyū 東洋思想研究 4 (1950): 1-46; Arai Ken 荒井健, “Sho-Tō no bungakusha to Bukkyō: Ō Botsu o chūshin to shite” 初唐の文学者と仏教: 王勃を中心として, in Chūgoku chūsei no shūkyō to bunka 中国中世の宗教と文化, ed. Fukunaga Mitsuji 福永光司 (Kyoto: Jinbun kagaku kenkyūjo, 1982), 575-88; Sun Changwu 孫昌武, Tangdai wenxue yu fojiao 唐代文學 與佛教 (Xi'an: Shaanxi renmin chubanshe, 1985); Sun Changwu, Chansi yu shiqing (zengdingben) 禪思與詩情 (增訂本) (Beijing: Zhonghua shuju, 2006); Chen Yunji 陳允吉, Fojiao yu Zhongguo wenxue lungao 佛教與中國文學論稿 (Shanghai: Shanghai guji chubanshe, 2010);Zhou Yukai 周裕锴, Wenzi Chanyu Songdai shixue 文字禪與宋代詩學 (Beijing: Gaodeng jiaoyu chubanshe, 1998); Hsiao Li-hua 蕭麗華, Tangdai shige yu Chanxue 唐代詩歌與禪學 (Taipei: Dongda tushu gongsi, 1997); Chen Yinchi 陳引馳, Sui-Tangfoxue yu Zhongguo wenxue 隋唐佛學與中國文學 (Nanchang: Baihuaizhou wenyi chubanshe, 2002); Zhang Bowei 張伯偉, Chan yu shixue (zengdingban) 禪與詩學 (增訂版) (Beijing: Renmin wenxue chubanshe, 2008); and Zheng Acai 鄭阿財, “Lun Dunhuang wenxian dui Zhongguo Fojiao wenxue yanjiu de tuozhan yu mianxiang” 論敦煌文獻對中國佛教 文學, Changjiang xueshu 長江學術 44 (2014.4): 28-38. Closely related topics include poetmonks (shiseng 詩僧), Dunhuang song lyrics 敦煌曲子詞, and the development of the “four tones and eight faults" 四聲八病 in poetics, each of which contains its own robust tradition of scholarship. I will address these as needed throughout the remainder of this essay but will not introduce them here.

16) Monier Monier-Williams, A Sanskrit-English Dictionary:Etymologically and Philologically Arranged, with Special Reference to Cognate Indo-European Languages, new ed. (Delhi: Munshiram Manoharlal Publishers, 2004), $35^{2}$.

17) Sigfried Lienhard, A History of Classical Poetry: Sanskrit_Pāli-Prakrit (Wiesbaden: Otto Harrassowitz, 1984), 80-81; on the collection more generally, see 80-86. The versions of this anthology which survive to the present likely postdate its earliest compilation by another 200-400 years. Critics also refer to this genre of single-stanza verses by a later term, muktaka. 
mystery" for future commentators due to its "nearly insurmountable interpretive challenges." ${ }^{18}$ Written in Māhārāșțī Prakrit, the gāthās nevertheless became models for elite Sanskrit poetry, accruing elaborate commentaries and being quoted in many poetics treatises. ${ }^{19}$ Likely of a similar age to the secular Gāhāsattasaī, at least in their earlier layers, are the Buddhist collections Theragāthā (Songs of the monks) and Therigātha (Songs of the nuns). ${ }^{20}$ These works, unlike the Gāhäsattasaī, range anywhere from one to seventy-four stanzas in length, though the majority fall on the shorter end of this spectrum. Though mainly didactic in content, many of these Pāli verses show flashes of literary brilliance, especially in the portions describing the natural surroundings in which religious goals are attained. ${ }^{21}$

In the context of the Buddhist scriptures, gāth $\bar{a}$ came to designate the verse parts of a sütra, as opposed to the prose (Ch. changxing 長行). It is important to note that these are most likely the oldest layers of a given scripture. ${ }^{22}$ In classic India, which placed great emphasis on phonology and primarily esteemed oral texts over written ones, the use of meter would have aided memorization of texts. The gāthās were the core of a sütra, the prose sections the elaborations thereof. As Maurice

18) Martha Ann Selby, "Desire for Meaning: Providing Context for Prākrit Gāthās," Journal of Asian Studies 55 (1996): 81.

19) Ibid., 81-93, for more on these commentaries. For translations of some of these gāthās, see Arvind Krishna Mehrotra, The Absent Traveller:Prākrit Love Poetryfrom the Gāthāsaptaśat̄ of Sātavāhana Hāla (1991; rpt. New Delhi: Penguin Books India, 2008).

20) On the basis of tradition, doctrines espoused, meters employed, and linguistic peculiarities, Leon Norman proposes that the verses were chiefly composed between the fifth and third centuries BCE (Norman, "Introduction" in The Elders'Verses, 2nd ed., 2 vols. [Lancaster: Pali Text Society, 2007], 1:xxxiv and 2:xxxi).

21) See Lienhard, A History of Classical Poetry, 76-78; Norman, The Elders' Verses, 1:xxvi.

22) See, e.g., Leon Hurvitz's remarks in the preface to his translation of the Lotus Sütra, The Scripture of the Lotus Blossom of the Fine Dharma, rev. ed. (New York: Columbia Univ. Press, 2009), $\mathrm{xx}$-xxi. Anthony K. Warder, in Indian Kāvya Literature, vol. 2: The Origins and Formation of Classical Kärya (New Delhi: Motilal Banarsidass, 1974), 22, dates the verse portions of the Pāli Buddhist canon to 500-100 BCE. Despite the fact that, according to Buddhist tradition, the canon was not set down in writing until the first century вСЕ., Maurice Winternitz believes we can confidently date most of the Pāli canon to the third century BCE. (History of Indian Literature, vol. 2: Buddhist Literature and Jaina Literature, trans. S. Ketkar and H. Kohn, second ed. [Calcutta: University of Calcutta, 1972; rpt. 1977], 15-16). However, we should note that a closed, stable "Pāli canon" was not reified as such for many more centuries, on which see Steven Collins, "On the Very Idea of a Pāli Canon," Journal of the Pali Text Society 15 (1990): 89-126. 
Winternitz notes about the Mahā-Parinibbāna-Sutta, "the verses...bear the stamp of greatest antiquity" and "surely belong to the oldest part of the Tipițaka." ${ }^{23}$ The ga $\bar{t} h \bar{a}$ was among the primary means of transmitting a master's teachings to his disciples.

Thus, the first Chinese gāthās appeared in the earliest sūtra translations, which emerged in the late second century CE. Like most terms carried over from the Indic languages into Chinese, ga $\bar{t}$ h $\bar{a}$ was translated and transliterated in a variety of ways, often to very different ends. We can classify the terms that have been used to refer to gāthās in medieval China into six categories: ${ }^{24}$

1. Jue 絕. This is the earliest extant rendition of the term. It is especially prominent in translations of An Shigao 安世高 (second cent. CE), which introduces gāthās with the phrase conghou shuo jue 從後說絕 ("after this says the $j u e$ "). As numerous previous scholars have noted, jue is most likely a transliteration of gāthā, since the character is pronounced something like *dzyat in the Late Han. ${ }^{25}$ Jue appear in both

23) Winternitz, History of Indian Literature, 38-40. Earlier he writes of the Pāli canon that "the metre, too, indicates the verse aphorisms (gāthā) in particular are very old" (p. 3). Cf. Chen Yunji, who notes that it is likely that the historical Buddha and his disciples primarily transmitted their early teachings through gāthās (Fojiao yu Zhongguo wenxue lungao, 2-3). 24) My list is adapted, with modifications, from Li Xiaorong 李小㮡, Hanyi fodian wenti ji qi yingxiang yanjiu 漢譯佛典文體及其影響研究 (Shanghai: Shanghai guji chubanshe, 2010), 89-108. For slightly different approaches to the definition of $g \bar{a} t h \bar{a}$, see Wang Jinghui 王睛慧, Liuchao Hanyi fodian jisong yu shige zhi yanjiu 六朝漢譯佛典偈頌與詩歌之 研究, Gudian wenxian yanjiu jikan 古典文獻研究輯刊, 2nd ser., vols. 16-17 (Yonghe: Hua Mulan wenhua chubanshe, 2006), 27-38; and Saitō Takanobu 齊藤隆信, Kango Butten ni okeru ge no kenkyū 漢語仏典における偈の研究 (Kyōto: Hozokan, 2013), 147-98. The latter goes into more detail than I do on the relative popularity of the various terms for gāthā in different time periods.

25) See Erik Zürcher, "A New Look at the Earliest Chinese Buddhist Texts," in From Benares to Beijing: Essays on Buddhism and Chinese Religion in Honour of Prof.Jan Yün-Hua, ed. Shinohara Koichi and Gregory Schopen (Oakville, Ontario: Mosaic Press, 1991), 295, in which the author is nevertheless puzzled by the initial ${ }^{*} d z$ - as a transcription of ${ }^{*} g$-. Li Xiaorong notes the possibility that jue could be a transliteration of geya, which I find unconvincing because of the abrupt dental final of jue in Late Han and Middle Chinese pronunciation (he also attributes this proposal to Sun Shangyong 孫尚勇, "Fojing jisong de fanyi tili ji xiangguan wenti”佛經偈頌的翻譯體例及相關問題, Zongjiaoyanjiu 宗教研究 2005.1:65-70, but the article actually says no such thing). When putting forth his own position, Li Xiaorong is a bit more nuanced, maintaining that jue originally transcribed the root gai which underlay gāthā, but that in later Chinese texts it sometimes referred to geya (Hanshifodian wenti, 91). For 2nd-4th century CE Chinese reconstructions, I have used the Late Han of Axel Schuessler, Minimal Old Chinese and Later Han Chinese: A Companion to Grammata Serica Recensa 
prose and verse forms, in a variety of meters and lengths without consistency and occasionally abbreviate the contents of the original material. In later translations, this term is sometimes used interchangeably with $j i$ 偈 and song 頌 on the very same page of a text. ${ }^{26}$ Interestingly, Dharmarakșa 笂法護 (d. 316), in his translation of the Sütra of the Questions of Suvikrāntacinti-devaputra, Spoken by the Buddha (Foshuo Xuzhen tianzi jing 佛説須眞天子經), combines the transcription jue with the translation ju ("verse") to create the earliest use of the term jueju 絕句. ${ }^{27}$

2. Ji 偈, song 頌, jiju偈句, jisong 偈頌. A combination of transliteration and translation, $j i$ (Late Han: * giat) transliterates the Indic syllable gäth-, while song means "hymn" and ju "verse." Though these words first appeared in a second-century translation, ${ }^{28}$ they became the standard thanks to Kumārajīva's 鳩摩羅什 (fourth cent.) use of them in his widely-read renditions of many sūtras. ${ }^{29}$

3. Qiye 祇夜. This is a transliteration of Sanskrit geya or "song" (Late Han: $\left.{ }^{*} g i e-j a^{c}\right)$, an alternative nominalization of the same root (gai) that

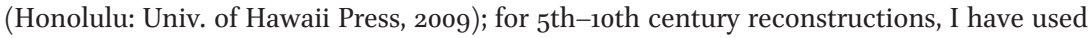
the Middle Chinese of William H. Baxter and Laurent Sagart, Old Chinese: A New Reconstruction (Oxford: Oxford Univ. Press, 2014).

26) See, e.g., the Dengji zhongde sanmeijing 等集衆德三昧經 (Skt: *Sarva-punya-samuccaya-samādhi sūtra, or the Sūtra on samādhi of gathering of all virtues), trans. Dharmarakșa 䇥法護 (d. 316), which refers to "hymns" (zhusong 諸頌), a "four-line short verse" (siju zhi jue 四句之絕), and “this gāthā" (ciji 此偈). The passage appears in T381: 12.979a-b.

27) For this earliest use of jueju, see T588: 15.104a. Li Xiaorong and Wu Haiyong 吳海勇 rather ingeniously suggest that this may have contributed to the rise of the namejueju in its technical literary sense, which indicates a poem in four lines ("Fojing jisong yu zhonggu jueju de deming” 佛經偈頌與中古絕句的得名, in Fojing wenxue yanjiu lunji 佛經文學研 究論集, ed. Chen Yunji et al. [Shanghai: Fudan daxue chubanshe, 2004], 348-59). However, the evidence for this hypothesis is rather thin and speculative-I concur with Saitō Takanobu that it is "a somewhat forced theory" (Kango Butten, 153). The earliest uses of jueju in its technical sense that we can confidently say were not imposed by later editors can be found in the sixth-century poetry anthology Yutai xinyong 玉臺新詠. On this point, see Daniel Hsieh, "On the Origins and Development of Jueju Verse" (Ph.D. diss., Univ. of Washington, 1991), 46.

28) Namely, the Banzhou sanmei jing 般舟三昧經 (Pratyutpanna-samādhi sūtra), translated by Lokakșema 支婁迦讖 (late 2nd cent. CE).

29) Sun Shangyong makes the rather controversial claim that $j i$ 偈 is in fact a transliteration of geya, not gātha ("Fojing jisong de fanyi tili ji xiangguan wenti," 65 ). His proposal is unconvincing since, again, it ignores the importance of the abrupt dental final in ji's Late Han pronunciation. Moreover, his only points of evidence are a handful of quotations cherrypicked from medieval Chinese commentaries, foregoing the more sound method of comparing translated texts with Indic versions. 
underlies gāthā. It refers more narrowly to verses contained within scriptures that summarize or elaborate upon the prose sections. In traditional divisions of the Buddhist canon into nine or twelve genres of texts, geya and gātha are considered to be distinct. ${ }^{30}$ However, in the actual use of these terms, outside of heuristic classifications, the terms can be used interchangeably.

4. Qieta 伽他, qietuo 伽陀. Another transliteration of the Sanskrit gātha (Late Han: *ga-tha/dai, Middle Chinese: *gja-tha/da), which frequently referred to verses that could circulate independently of longer sütras. This transliteration became more popular in the Tang among those monks who knew something about Sanskrit. The pronunciation of $j i$ underwent a vowel shift between its Late Han and Middle Chinese stages $\left({ }^{*}\right.$ giat $\rightarrow{ }^{*}$ gjet $)$, making the older transliteration inaccurate to Tang ears. ${ }^{31}$

5. Shouluke 首盧柯, shilujia 室路迦, shulujia 輸盧迦, etc. These are transliterations of a different Sanskrit word, śloka, which means "stanza." Very often, this referred more specifically to a stanza in the Anuștubh meter, comprised of four lines of eight syllables each. However, as authoritative a source as the Yiqiejing yinyi一切經音義 (Pronunciations and meanings for all scriptures) equates śloka with $g \bar{a} t h \bar{a}(j i) \cdot{ }^{32}$

6. Zazan 雜讚, zan 讚. A translation meaning "assorted praises," used in the titles of self-contained $g \bar{a} t h \bar{a}$ collections. Although this term may have originally translated stotra ("hymn of praise"), it soon came to be

30) For example, the Mahāparinirvāna sūtra (Dabanniepan jing 大般涅槃經) lists the nine genres of texts in the canon as: 1) sūtra 修多羅 or scriptures, 2) geya 祇夜 or songs, 3) vyākarana 受記 or assurances of future liberation, 4) gāthā 伽陀 or verses, 5) udāna 優陀那 or unprompted teachings of the Buddha, 6) itivrttaka 伊帝目多伽 or reported past lives of the Buddha, 7) jātaka 闍陀伽 or stories of the Buddha's previous incarnations, 8) vaipulya 毘佛略 or expanded teachings, and 9) abhuta-dharma 阿浮陀達磨 or miraculous deeds of the Buddha. See T375: 12.623b.

31) See, e.g., the discussion in Woncheuk 圓測 (613-696), "Commentary on the Samdhinirmocan sūtra” (Jie shenmi jing shu 解深密經疏, Z369: 21.211b): “The real Sanskrit pronunciation is qietuo ("gja-da). Since it should sound like qie (" $\left.{ }^{*} g j a\right)$, it should not be called ji ("gjet). Though there are two explanations, the former is the correct one. There are many realms in the west with languages that sound different: central India calls it qietuo, while the rest [of India] calls it qieta. Only when we come to Khotan is it called ji.” 梵音正是伽陀。即應言 伽, 不應名偈。雖有兩釋, 前說為正。西方諸國, 語音不同: 中印度國名為伽 陀, 餘處名伽他。乃至于闐國名為偈他。For more on pronunciation shifts and the need to create these new transliterations, see Saitō Takanobu, Kango Butten, 166-81.

32) T2128: 54.741c. 
mixed up with verses originally labeled gāthā or geya. ${ }^{33}$ This very fact stresses the similarities between $g \bar{a} t h \bar{a}$ s and the Chinese verse genre zan ("praise [song]"), which I will discuss in greater detail below. Zazan in this sense first appears in the Sütra of Assorted Praises Spoken by the Buddha 佛説雜讃經, translated by Dharmarakșa in 285. The Assorted Praises was originally a section of the Jātaka sūtra 生經 (T154) but soon came to circulate independently. ${ }^{34}$

As this list shows us, the terminology for gāthā and related Sanskrit words (geya, śloka, stotra) was never precise. Later commentators, following the traditional nine- or twelve-fold classification of the canon, tried to draw hard and fast distinctions between qiye and qieta, but their rectified names never caught on with the public. For the purpose of this essay, I will use gāthā to mean ji or jisong, understanding it as an umbrella term that covers all six uses given above.

\section{The Gāthā in the Early Medieval Period}

To a modern reader, most of the early gāthās contain very little literary value, coming from "versifiers turning out their rather monotonous products by the yard," to use Erik Zürcher's colorful description. ${ }^{35}$ However, these $g \bar{a} t h \bar{a}$ s approximate at least the form of poetry: nearly all of them are in four- or five-character meter, and most of the latter type have a caesura after the second character. ${ }^{36}$ Moreover, a minority even rhyme. One such work is the Middle-length Sütra of Past Events (Zhong benqijing 中本起經; T196), a narrative of the life of the Buddha

\footnotetext{
33) On this point, see Chen Ming 陳明, "Hanyi fojingzhong de jisong yu zansong jianyao bianxi” 漢譯佛經中的偈頌與贊頌簡要辨析, Nanya yanjiu 南亞研究 2006.2: 55-56.

34) For the Sütra of Assorted Praises Spoken by the Buddha, see T154: 3.103b-c. On its independent circulation under the title Sütra of Assorted Praises 雜讃經, see its entry in the catalogue Chu sanzang jiji 出三藏記集, compiled in 515 (T2145: 55.28c).

35) Zürcher, "Vernacular Elements in Early Buddhist Texts: An Attempt to Define the Optimal Source Material," Sino-Platonic Papers 71 (1996): 10.

36) According to the calculations of Sun Shangyong, $82 \%$ of all pre-Song gāthās in the Taishō canon are in five-character meter and $13 \%$ are in seven-character meter, leaving a mere $5 \%$ in all other forms. See Fojiao jingdian shixue yanjiu 佛教經典詩學研究 (Beijing: Gaodeng jiaoyu chubanshe, 2013), 20. Saitō Takanobu believes this tendency for five-character meter, which emerges during the Three Kingdoms period and dominates until the early Tang, is due to the influence of literary developments during the Jian'an era (Kango Butten, 67). On the tendency of $g \bar{a} t h \bar{a}$ s to observe the proper caesuras of elite verse, see Saitō Takanobu, Kango Butten, 94-99.
} 
translated by Kang Mengxiang 康孟詳 and Zhu Dali 朱大力 sometime during the Jian'an 建安 period (196-220) at the very end of the Han dynasty, based on texts brought from India by Tanguo 黄果. ${ }^{37}$ The scripture contains twenty gāthās, all introduced with the formula "and he produced a hymn" (er zuo song yue 而作頌曰), six of which rhyme. One of them, describing the body of the Buddha as he escapes the flames of a dragon, reads:

\begin{tabular}{|c|c|c|}
\hline 容顏紫金耀 & Facial features, purple and gold shining, & - \\
\hline 面滿髮紺青 & A head round, hair dark blue, & $t s^{h} e y$ \\
\hline 大人百福德 & The Great Man: a hundred meritorious virtues, & - \\
\hline 神妙應相經 & His wondrousness complies with the Sütra on the Marks,,$^{38}$ & key \\
\hline 立丈六 & His square body standing sixteen feet tall, & - \\
\hline 十章 & His appearance fine, with the eighty marks, & tśay \\
\hline 頂方 & His halo like a candle in the dark- & - \\
\hline 何駅忽無 & How quick and extraordinary! ${ }^{39}$ & dźar \\
\hline
\end{tabular}

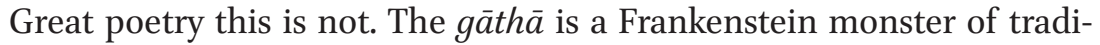
tional epithets of the Buddha's physical demeanor, stitched together with the threads of pentameter. The Sütra on the Marks describes the thirty-two main physical features of a Buddha, while the "eighty marks" refer to yet another list of his physical features (more commonly called bashi suihao 八十隨好). ${ }^{40}$ Sixteen feet is the height traditionally given to the Buddha's glorified body. In terms of poetic craftsmanship, the parallelisms in these lines are lacking. The color words of line 1 (zijin 紫金) appear as the third and fourth characters of the line, while the color words of line 2 (ganqing 紺青) appear as the fourth and fifth characters. The two halves of the couplet are not aligned. The same is true of

\footnotetext{
37) See the early Buddhist catalogue Chu sanzang jiji 出三藏記集, comp. Sengyou 僧祐 in 515 (T2145:55.6c7-8). On the reliability of dating this scripture to the late Han, see Jan Nattier, A Guide to the Earliest Chinese Buddhist Translations: Texts from the Eastern Han and Three Kingdoms Periods (Tokyo: International Research Institute for Advanced Buddhology, Soka University, 2008), 102-9.

38) The Sūtra on the Marks is an abbreviation of the Sütra on the Thirty-two Marks 三十二 相經, a chapter of the Middle-length Āgama Sütras which describes the thirty-two unique physical features of the Buddha (T26: 1.493a-494b).

39) T196: 4.148c11-14.

40) For more on the Buddha's physical traits and their relationship to early Buddhist concepts of masculinity, see John Powers, A Bull of a Man: Images of Masculinity, Sex, and the Body in Indian Buddhism (Cambridge, Mass.: Harvard Univ. Press, 2009), 1-66.
} 
the numbers mentioned in lines 5 and 6 (as the fifth and the third characters of their respective lines).

Despite these deficiencies, there is a real attempt at poeticizing the $g \bar{a} t h \bar{a}$ here. A pause after the second character, common to pentametric poetry, is observed in every line. What is even more important is the fact that the even lines rhyme, albeit in a simple AABB pattern. But the rhyme is stronger than this suggests: the two halves of the poem form a half-rhyme with each other, since all of the rhyme words end with a nasal final. These sorts of quasi-rhymes between nasal-final words were quite common in the late Han dynasty. ${ }^{41}$ Moreover, the gāthā shows an awareness of tones: while all the rhyme words are level tones (pingsheng 平聲), the final characters of odd-number lines have other tones (what would later be called the "oblique" or zesheng 入聲 category). This rule, that one's non-rhyme end characters should belong to a different tonal category from one's rhyme words, became standard for regulated verse (lüshi 律詩) several centuries later.

Note how this gāthā observes the nascent Chinese rules of poetry. Rhyme was never one of the main structuring features of early South Asian poetry, not being native to any Indo-European poetic tradition. ${ }^{42}$ Rhyme was a distinctly Chinese poetic feature; Sanskrit and Prakrit poetry were characterized by their elaborate meters and chanting practices. Thus, in adding rhyme to an unrhymed original, the translator Kang Mengxiang intends to make it adhere to Chinese standards of literariness. He has consciously tried to poeticize it. To Kang Mengxiang, the

\footnotetext{
41) On this point, see Nicholas Morrow Williams, "The Half-Life of Half-Rhyme," Early Medieval China 17 (2011): 22-50, esp. 42.

42) See Indira Viswanathan Peterson, Design and Rhetoric in a Sanskrit Court Epic: The Kirātārjunīya of Bhāravi (Albany: State Univ. of New York Press, 2003): "A major principle of $k \bar{a} r y a$ is the avoidance at every level of linearity, symmetry, and repetition of an obvious kind...Within the framework of the stanza, for example, the poets will use alliteration, not rhyme, balanced structures, but not simple parallelism." See also T. V. F. Brogan et al., "Rhyme," in The Princeton Encyclopedia of Poetry and Poetics, 1182. Siegfried Lienhard remarks that the "predilection for rhyme" in the poems of Jayadeva (fl. c. 1200) marks "the first appearance" of the device in high Sanskrit poetry and betrays the influence of popular verse $(A$ History of Classical Poetry, 207). This is not to say that Sanskrit poetry completely eschewed rhyme (yamaka) and wordplay, only that it was seen more as a kind of ornament (alamkāra) than an essential feature of poetry. For more on wordplay in South Asian poetic traditions, see Yigal Bronner, Extreme Poetry: The South Asian Movement of Simultaneous Narration (New York: Columbia Univ. Press, 2010).
} 
gāthās of the scriptures resembled poetry and should thus be translated into poetry. ${ }^{43}$ For six of the twenty gāthās of the Zhong benqi jing, this meant using rhyme.

This practice never became standard for translated scriptures. In the corpus of An Shigao 安世高 (mid-second cent.), there are no rhymed $g \bar{a} t h \bar{a}$ s to be found in the scriptures that can be confidently attributed to him. ${ }^{44}$ More generally, in Saitō Takanobu's exhaustive study of $g \bar{a} t h \bar{a}$ s in translated Chinese sūtras, he finds only 116 rhymed gāthās, out of many thousands, in sixty scriptures within the Taishō canon. Most translators, it seems, were content to render these gāthās into an even number of four-, five-, or seven-character lines.

In the Six Dynasties period, gāthās were not considered poetry, nor did they seem to be a threat to the definition of poetry. Embedded in sacred texts, they were seen as distillations of those texts. They could function as shorthand for the main teachings of a sütra, and they could take on the same powers of the scriptures. For this reason, gāthās were highly valued possessions, often called baoji 寶偈 ("precious gāthās").45 A story in the Mahāparinirvāṇa sūtra relates how Śākyamuni Buddha was delighted upon hearing a "half-gāth $\bar{a}$ " 半偈 on impermanence from the god Indra:

諸行無常 All actions are impermanent:

是生滅法 This is the dharma of arising and extinction.

The Buddha prized it so greatly that he offered his life to Indra to hear the second half:

43) This point, on the "poeticization" (shihua 詩化) of gāthās, has also been made by Tan Zhaowen 譚召文 in Chanyue shihun: Zhongguo shiseng zongheng tan 禪月詩魂：中國詩 僧縱横談 (Beijing: Shenghuo, Dushu, Xinzhi sanlian shudian, 1994), 7-15, albeit without clear definitions of "poetry" and "gāthā." Some scholars have raised the possibility that the text of the Zhong benqi jing we have today was in fact revised after Kang Mengxiang's time; thus it may have been someone else who consciously tried to poeticize the gāthās. See Nattier, A Guide to the Earliest Chinese Buddhist Translations, 105-9.

44) Saitō Takanobu lists three rhymed gāthās in three scriptures attributed to him, none of which are reliable (Kango Butten, 630-37). On An Shigao's corpus, see Nattier, A Guide to the Earliest Chinese Buddhist, 35-72.

45) I find thirty-four uses of baoji in the Taishō canon, plus fifteen more in QTW (excluding occurrences of sanbaoji 三寶偈 or "gāthā on the three treasures"). 
生滅滅已 When arising and extinction are extinguished,

寂滅爲樂 Silent extinction is joy. ${ }^{46}$

The $g \bar{a} t h \bar{a}$ here is valued for the eternal truth it contains, not for any aesthetic feature. However, a poetic principle is the key on which the story turns. The Buddha must recognize that a single couplet is not a complete piece, but only a "half," in order to ask for more. There is an unspoken assumption that a gāthā, like a shi-poem, must have at least four lines. Delighted by hearing the truth of the first half, the Buddha knows there must be more to it, and so goes to great lengths to hear the full thing. This story of the half-gāth $\bar{a}$ became a reference point for many Tang poets, including Liu Yuxi 劉禹錫 (772-842) and Wen Tingyun 溫庭笉 (812-870), who alluded to it in poems written at temples or presented to monks.

This distillation function of gāthās, coupled with their generally celebratory or joyful tone, explains why they were most closely associated with the terms song 頌 ("hymn") and zan 贊／讚 ("praise"; "summary verse") during the early medieval period. Both song and zan were types of verse valued for their function more than their beauty. They were sometimes considered sub-categories of "poetry," sometimes not. In the literary theoretical work Wenxin diaolong 文心雕龍 (The Literary Mind and the Carving of Dragons), for example, each chapter concludes with an eight-line verse called a zan which pithily restates that chapter's main points. These function less as poems and more as capsule summaries. Many gāthās have the same relationship to the prose parts of sūtras as the Wenxin diaolong's zan do to their chapters. To take just one case, the commentary to the Shishuo xinyu tells us of a monk named Fasheng 法勝 who distilled the Abhidharmahrdaya-śāstra down to 250 gāthās which he "considered to be the essentials and called it the 'Heart' (Hrdaya)” 以為要解, 號之曰心. ${ }^{47}$ These $g \bar{a} t h a \bar{s}$, an abridged version of a text that is already an abridgment of other scriptures, are more a technology for managing the sheer volume of imported Buddhist texts than

46) Mahāparinirvāṇa sūtra (Ch. Da banniepanjing 大般涅槃經), T374: 12.450a-451a; trans. Dharmakșema 昙無讖 in 421.

47) Shishuo xinyu jianshu 世說新語箋疏 (Taipei: Huazheng shuju, 1984), “Wenxue” 文學 no. 64, 4.242; cf. Richard Mather, trans., Shih-shuo Hsin-yü: A New Account of Tales of the World, 2nd ed. (Ann Arbor: Univ. of Michigan, Center for Chinese Studies, 2002), 132-33. The late fourth-century monk Samghadeva 僧伽提婆 is said later in the commentary to have appreciated these $g \bar{a} t h a \bar{s}$, so Fasheng must have compiled his gāthās some time prior to this. 
they are works of literature. In this way, the gāthā does not directly impinge upon the territory of shi. Its territory is the margins of song and $z a n$, which themselves are located on the margins of shi. The gätha $\bar{a}$ is therefore two steps removed from the prestigious term "poetry."

Another reason gäthās were associated with the genre of "hymns" (song) is because both are directed toward the spirit world. In Zhi Yu's 摰虞 early fourth-century treatise on genres, Wenzhang liubie lun 文章 流別論, hymns are described thus:

Hymns are poems that praise. In the past, when the sagely emperors and brilliant kings accomplished great things and brought peace, the melodies of the hymns arose. Then, the scribes recorded these works, the musicians sang their stanzas, and they were presented in the ancestral temples and proclaimed to the deceased and to the spirits. ${ }^{48}$

頌, 詩之美者也。古者聖帝明王, 功成治定, 而頌聲興。于是史錄其篇, 工歌 其章, 奏于宗廟, 告于鬼神。

These praise-poems were never simply songs about the heroes of old; they were songs sung for the heroes of old, that they might watch over the living. Hymns are performative as much as they are aesthetic: they are proclaimed to the spirits, who then offer their blessing and protection. They are like spells, meant to be efficacious. The aesthetic features of hymns are directed toward this goal: sonorous, well-crafted lines of verse will more greatly please the departed.

It is easy to see why gāthās, which were also held to have magical powers, became associated with hymns. A story about the monk Huiyuan 慧遠 (334-416) tells us of this talismanic function of gāthās.

When the monk Huiyuan was living at Mt. Lu, a roaming dragon once flew in front of him. Only after Huiyuan's servant threw rocks at it did it soar up and fly away. Shortly thereafter, the winds began to blow hard and the clouds shine bright. Huiyuan, knowing that this was the dragon's doing, climbed to the top of the mountain, burned incense, and chanted gāthās in one accord with the other monks. Thereupon, a thunderbolt struck the rocks that were thrown at the dragon, and the rain-clouds dispersed. ${ }^{49}$

48) Quan Jin wen 全晉文 $77.7 \mathrm{~b}$ (p. 1905a).

49) Liu Jingshu 劉敬叔 (fl. early fifth cent.), Yiyuan 異苑 5.641, in Han Wei Liuchao biji xiaoshuo daguan 漢魏六朝筆記小說大觀, ed. Wang Genlin 王根林 (Shanghai: Shanghai guji chubanshe, 1999). For an overview of the Yiyuan, see Robert Ford Campany, Strange 
沙門釋慧遠棲神盧岳, 常有遊龍翔其前。遠公有奴, 以石橂中, 乃騰躍上升。 有頃, 風雲葙煜。公知是龍之所興, 登山燒香, 会僧齊声唱偈。於是霹靂回向 投龍之石, 雲雨乃除。

In this story, the chanting of $g \bar{a} t h \bar{a}$ s is one of the ritualistic mechanisms by which the dragon is pacified. The performance of a gātha, like the burning of incense, is efficacious: it contains within it the numinous power of the sütra, amplified by the monks' collective merit. Though the story does not tell us which gāth $\bar{a}$ was recited, nor how long it was, nor what were its formal qualities, the story does make clear that its purpose is not merely didactic, an aide-mémoire; the gāthā is a verbal weapon wielded against malevolent forces. Its power is the power of the Dharma, concentrated in a few lines of verse.

This numinous power of the $g \bar{a} t h \bar{a}$ is seen all throughout the Mahāyāna scriptures. It is closely associated with the "cult of the book" which privileged the copying, recitation, and upholding of sūtras over other forms of meritorious practice, such as the reverence shown for a stüpa or the slow cultivation of virtuous behavior. Indeed, the very spot where a sacred text-including its gāthās — was copied was to be treated as sacred ground. ${ }^{50}$ In the Mahāyāna-karuñā-puṇ darīka sūtra (Dasheng bei fentuoli jing 大乘悲分陀利經), the Buddha explains the scripture's efficacy to his disciples:

If you are good men and good women, uphold this sūtra: read it, recite it, write it, copy it, and explain it to others. For with even a single four-line $g \bar{a} t h \bar{a}$, people will attain blessings that surpass the six pāramitās [perfections] of all the actions of a bodhisattva throughout ten great kalpas. ${ }^{11}$ How is this so? It is because this sūtra is able to eliminate the wicked minds of the gods, the people of this world, Brahmā and Māra, the śrāmaṇas, and the brahmins; of the assemblies of rākșasas, dragons,

Writing: Anomaly Accounts in Early Medieval China (Albany: State Univ. of New York Press, 1996), 78-80.

50) On the cult of the book, see Gregory Schopen, "The Phrase 'sa prthivīpradeśaś caityabhūto bhavet' in the Vajracchedikā: Notes on the Cult of the Book in Mahāyāna," Indo-Iranian Journal 17 (1975): 147-81. For a challenge to some aspects of Schopen's landmark article-including the idea that sūtra-veneration was original to Mahāyāna (positing instead that it was shared by other varieties of Indian Buddhism) — see David Drewes, "Revisiting the Phrase 'sa prthivīpradeśas caityabhūto bhavet' and the Mahāyāna Cult of the Book," Indo-Iranian Journal 50 (2007): 101-43. On the cult of the book in the Chinese Buddhist context, see John Kieschnick, The Impact of Buddhism on Chinese Material Culture (Princeton: Princeton Univ. Press, 2003), 164-85.

51) Ten great kalpas, according to typical calculations, would equal 10,334,000,000 years. 
gandharvas, Kumbhānda, hungry ghosts, piśācī, kimnaras, and asuras. ${ }^{52}$ It is also able to eliminate all illnesses, disputes, and enmity. It is also able to eliminate malicious winds, frost and hail, and monsoons which occur out of season. It is also able to eliminate epidemics and famines. ${ }^{53}$

若有善男子善女人, 受持是經 : 讀、誦、書、寫、爲他人説。乃至一四句偈, 是人得福過於菩薩十大劫中具行六波羅蜜者。所以者何? 此經能滅除諸天世 人、梵魔、沙門、婆羅門, 衆夜叉、羅刹、龍、乾闥婆、鳩槃茶、餓鬼、毗舍 遮、緊那羅、阿修羅等諸惡心故。又能除滅一切諸病、鬦猙、怨疥。又能除滅 非時惡風、霜雹、暴雨。又能除滅疾疫、飢饉。

This passage continues listing the scripture's benefits for another eight lines, but we need not go farther. We see that in this excerpt, a four-line gāthā (Ch. siju ji 四句偈; Skt. catuṣpādika gāthā) is mentioned as the smallest possible unit of a sūtra, yet it still contains all of its efficacy. From this, we can see that the power of a sūtra operates according to the principle of metonymy: part may be substituted for the whole. The merit produced by upholding only a four-line gāthā is greater than the merit accumulated by a bodhisattva over lifetimes. This speaks, of course, to the scripture's efficacy, but also to the potential embedded within each gāthā. Similar passages can be found throughout many Mahāyāna scriptures and would have been generally accepted by the Buddhist faithful. ${ }^{54}$ Any excerpted gātha could be recited in times of need to access its sūtra's powers in the seen and unseen realms.

A $g \bar{a} t h \bar{a}$ 's numinous powers stemmed not only from its role as a distillation of scriptures, but also from the aesthetic quality of its recitation. In a brief anecdote in the Yin Yun xiaoshuo 殷去小說, the poet-prince Cao Zhi 曹植 (192-232) is stirred by the sound of sonorous Sanskrit chants.

Although the Buddha-dharma in China began with Emperor Ming of the Han, the scriptures and gāthās were nevertheless originally foreign sounds. Prince $\mathrm{Si}$ of Chen [Cao Zhi] climbed Mt. Yu, surveyed Dong'e, and heard the sound of sūtra recitation in the cliffs and peaks, pure and gentle, powerful and vibrant, its echoes flowing into the distant valleys. Reverent, Cao Zhi had numinous $q i$, and without

52) With the exception of śrämanas (renunciants) and brahmins, the transliterated Sanskrit terms refer to various types of more or less malicious supernatural beings, which I will not explain in detail here.

53) T158: 3.288c-289a.

54) Cf. T159: 3.331a; T187: 3.617a; T231: 8.725b; T232: 8.732b; T235: 8.749b; T262: 9.54a; etc. 
realizing it, he pulled on his lapels in respect, and he desired that he should come to his end there. All the officials understood the sound and thought it the very paragon of marvelous chanting, praising it and taking it as their standard. Nowadays, all Sanskrit chants are composed following Cao Zhi's. When Cao Zhi died, he was buried in this land. ${ }^{55}$

中華佛法, 雖始於漢明帝, 然經偈故是胡音。陳思王登漁山, 臨東阿, 聞岩岫 有誦經聲, 清婉遒亮, 遠谷流響, 肅然有靈氣, 不覺斂襟祇敬, 便有終焉之 志。諸曹解音, 以為妙唱之極, 即善則之, 今梵唄皆植依擬所造也。植亡, 乃 葬此土。

Though we need not take this anecdote as in any way reflecting historical reality, its very existence as a story testifies to the power that sūtras and gāthās were believed to have. The sound of a well-chanted gāthā, much like music, seems to have very literally resonated with Cao Zhi, stimulating from afar a response in him. ${ }^{56}$ The phrase I have translated as "had numinous qi," you lingqi 有靈氣, refers to an individual's capacity for receiving and responding to the spiritual stimulation of external things. ${ }^{57}$ Because Cao Zhi is so well-endowed in this regard, he is moved to the proper response of respect and awe without even knowing what he is doing. The aural beauty of the gāth $\bar{a}$ has moved through him.

55) Yin Yun xiaoshuo 5.1035, in Han Wei liuchao biji xiaoshuo daguan; and Lu Xun 魯迅, ed., Gu xiaoshuo gouchen 古小說鉤沈 (Hong Kong: Xinyi chubanshe, 1967), 113. This anecdote appears in a slightly different form in Yiyuan 5.641 (also collected in Han Wei liuchao biji xiaoshuo daguan). For more on the various versions of this anecdote, see T. P. K. Whitaker, “Tsaur Jyr and the Introduction of Fannbay 梵唄 into China," Bulletin of the School of Oriental and African Studies 20 (1957): 585-97. On the Yin Yun xiaoshuo, see Campany, Strange Writing, 89; on Yin Yun himself, see David R. Knechtges and Taiping Chang, eds., Ancient and Early Medieval Chinese Literature: A Reference Guide (Leiden: Brill, 2014), 4:1919-1922.

56) The range of the term Sanskrit term pätha expanded when it was translated into Chinese as fanbei 梵唄. Though in India pātha referred more narrowly to the chanting of the prose sections of sūtras, in China fanbei covered the chanting of hymns (zan), including gāthās. See Whitaker, “Tsaur Jyr,” 587. For more on fanbei, see Paul Demiéville, “Bombai 梵唄” in Sylvain Lévi and J. Takakusu, eds., Hōbōgirin, vol. 1 (Tokyo: Maison Franco-Japonaise, 1927), 93-96. On the importance of resonance in early Chinese discussions of music, see Kenneth DeWoskin, A Song for One or Two: Music and the Concept of Art in Early China (Ann Arbor: Univ. of Michigan, Center for Chinese Studies, 1982).

57) It is often used in parallel to "transcendent capacity" (xiancai 仙才) in early medieval verse. See, e.g., Guo Pu 郭璞, “Poems on Roaming with Transcendents: 6 of 19” 遊仙詩十九 首其六 (Lu Qinli 逯欽立, comp., Xian-Qin Han Wei Jin Nanbeichao shi 先秦漢魏晉南北 朝詩 (Beijing: Zhonghua shuju, 1984; hereafter “Lu Qinli”), 866) and Li Chang 李崉, “Poem on Accompanying the Imperial Tour to the Zhongnan Mountains”陪駕幸終南山詩 (Lu Qinli, 2324-25). 
Cao Zhi's response is both aesthetic and spiritual: the dharma is directly mentioned only at the very beginning, its power only hinted at. The sound of the recitations, however, is what has a direct though invisible effect on its listeners, inspiring a whole movement in chanting. The $g \bar{a} t h \bar{a}$, when recited properly, could work its magic on both the aesthetic and spiritual levels.

As such, the precise methods by which one chanted gāthās were supremely important for Buddhists of the time. And this leads us to yet another way in which gāthās related to the definition of poetry, a relationship which would only gain in importance during the Tang: the development of the four tones and the prosody of regulated verse. By the late fifth and early sixth centuries, there is evidence that Sanskrit chants had become very popular. ${ }^{58}$ As Chen Yinque 陳寅恪, Victor Mair, and Tsu-lin Mei have documented, the inventors of tonal prosody in the late fifth century (Shen Yue 沈約 and his circle) also showed great interest in Buddhism and its chanting methods. Around the same time Shen Yue wrote his treatise on prosody, prince Xiao Ziliang 蕭子良 had a dream of chanting before the Buddha, which prompted him to assemble masters of recitation in the capital to create a new method for performing gāthās. ${ }^{59}$ The categories of level 平 and oblique 大 tones may have emerged as a way of approximating the laghu (light) and guru (heavy) syllables of Sanskrit gāthās. Moreover, the lists of poetic "defects" (bing 病) in fifth- and sixth-century treatises appear to be adapted from similar Indian lists which became formalized by Bhāmaha and Daṇịin in the second half of the seventh century. ${ }^{60}$ If Mair and Mei's claim is correct, this means that even though the gāth $\bar{a}$ was two steps removed from what most people considered poetry, it was foundational to poetry's formal refinement and codification over the next several centuries. Though the gātha did not yet risk becoming a part of shi, this is precisely what

\footnotetext{
58) See, e.g., the list of twenty-one titles related to the topic in the Chu sanzang jïi ( $\mathrm{T}$ 2145: 55.92a-b); cf. Saitō Takanobu, Kango Butten, 454-56.

59) Chen Yinque 陳寅恪, “Sisheng sanwen” 四聲三問, Qinghua xuebao 清華學報 9.2 (1934): 275-85. For a summary of the Chinese evidence, Victor Mair and Tsu-lin Mei, "The Sanskrit Origins of Recent Style Chinese Prosody," Harvard Journal of Asiatic Studies 51 (1991): 375-470, esp. 378-79.

60) On the Sanskrit treatises, see Edwin Gerow, Indian Poetics (Wiesbaden: Otto Harrassowitz, 1977), 226-33; and Pollock, "Sanskrit Literary History," 42-44.
} 
was happening at a basic, structural level. Gäthās set the rules that poetry would have to follow. In spite of this, the two domains remained distinct for some time. It was only in the Sui and early Tang that serious confusion between "poems" and gāthās arose, a confusion that steadily grew over the three centuries of the Tang dynasty.

\section{Gäthä Collections in the Sixth to Eighth Centuries}

Given the blurry line between translation, commentary, compendium, summarization, and the production of indigenous scriptures in the Six Dynasties period, ${ }^{61}$ it should come as no surprise that gāthās, many originally composed in Chinese, could circulate independently of sūtras. Already in 515, we find a list of ten different gāthās or gātha collections circulating in single-fascicle editions, according to the Buddhist catalogue Chu sanzang jiji. They are listed between collections of allegories (Skt. avadāna; Ch. piyu 譬喻) and spells (Skt. mantra; Ch. zhou 呪) and seem to conceptually straddle this line as well:

\begin{tabular}{|c|c|}
\hline 梵音偈本一卷 & Volume of Indic gāthās, 1 fascicle. \\
\hline 陀羅尼偈一卷抄 & Dhäraṇi gāthās, 1 fascicle, selection. \\
\hline 阿彌陀佛偈一卷 & Amitābha Buddha $g \bar{a} t h \bar{a}, 1$ fascicle. \\
\hline 後阿彌陀佛偈一卷 & Later Amitābha Buddha gāthā, 1 fascicle. \\
\hline 七佛各説偈一卷 & Gāthās explained by each of the seven Buddhas, 1 fascicle \\
\hline 讃七佛偈一卷 & Gäthās in praise of the seven Buddhas, 1 fascicle. \\
\hline 深自知身偈一卷 & $\begin{array}{l}\text { Gāthā on deep self-knowledge of the body, } 1 \text { fascicle. } \\
\text { (舊録云自知偈) (Called “Gāthā on self-knowledge" in the } \\
\text { old catalogue.) }\end{array}$ \\
\hline 禪經偈一卷 & $\begin{array}{l}\text { Meditation manual } g \bar{a} t h \bar{a} s, 1 \text { fascicle. (抄禪經中偈) } \\
\text { (A selection of } g \bar{a} t h \bar{a} \text { s from meditation manuals.) }\end{array}$ \\
\hline
\end{tabular}

61) On this point, see the many contributions to Robert E. Buswell, ed. Chinese Buddhist Apocrypha (Honolulu: Univ. of Hawaii Press, 1990). Funayama Toru, in "Masquerading as Translation: Examples of Chinese Lectures by Indian Scholar-Monks in the Six Dynasties Period," Asia Major, 3rd ser., 19.1-2 (2006): 39-55, is especially provocative in this regard, showing evidence that audience discussion of a sūtra's meaning would sometimes be incorporated into the translation (which mainly took place in an oral context).

62) On meditation manuals, see the discussion in Nobuyoshi Yamabe, "The Sūtra on the Ocean-Like Samädhi of the Visualization of the Buddha: The Interfusion of the Chinese and Indian Cultures in Central Asia as Reflected in a Fifth Century Apocryphal Sūtra" (Ph.D. diss., Yale Univ., 1999), 59-114. 


\begin{tabular}{|l|l|}
\hline 恒惒尼百句一卷 & One hundred dhāraṇi verses, 1 fascicle. ${ }^{63}$ \\
\hline $\begin{array}{c}\text { 五言詠頌本起一卷 } \\
\text { (一百四十二首 })\end{array}$ & $\begin{array}{l}\text { Pentametric hymns on origins, } 1 \text { fascicle. } \\
(142 \text { pieces. })^{64}\end{array}$ \\
\hline
\end{tabular}

The titles of many of these works imply ritual use. Gäthās are equated with dhäranī, praise-poems, and meditation manuals, all of which are closely related to religious practice. Poetry, as an elite form of verbal art, is nowhere to be seen. None of these volumes is extant, except perhaps the "Amitābha Buddha gāthā," which may be a version of the "Gāthās in Praise of Amitābha Buddha” 贊阿彌陀佛偈 by Tanluan 曇鸞 (c. 476-572) now preserved in the Taisho canon (no. 1976). This collection contains 436 lines of verse, 428 of which are in heptameter, separated by fifty-one lines of obeisance to various bodhisattvas. The $g \bar{a} t h \bar{a}$ s range from four to twenty-six lines long, with no attempt made to rhyme. The first $g \bar{a} t h \bar{a}$, typical of the collection, reads:

南無至心歸命禮
西方阿彌陀佛
現在西方去此界
十萬億刹安樂土
佛世尊號阿彌陀
我願往生歸命禮
願共諸衆生往
安樂國

南無至心歸命禮 西光阿爾他佛 現在西方去此界

佛世尊號阿彌陀 我願往生蹄命禮 安樂國
Namo, I take refuge in and reverence Amitābha, Buddha of the West!

Now abiding in the West, having left this world For one hundred thousand kșetras-lands of peace and happiness,

The Buddha is honorably called Amitābha.

I wish to be reborn there, and take refuge in him.

I pray that I may be reborn with all sentient beings in the realm of peace and happiness. ${ }^{65}$

Aside from the length of the central lines, the $g \bar{a} t h \bar{a}$ s have very little in common with poetry being written at the time. Rhyme is absent, parallelism is kept to a minimum (jie 界 and $t u$ 土 in the first couplet, possibly Fo 佛 and $w o$ 我 in the second couplet), and they display no tonal regulation beyond the amount allowed by chance. These verses became important to Pure Land devotees for their use in rituals. They provided the

\footnotetext{
63) I take henghe'ni 恒惒尼 to be a mistake for dahe'ni 怛惒尼 (Middle Chinese *tat-hwanrij), an uncommon transliteration of dhäranī.

64) T2145: 55.31a13-22.

65) For a pious translation of the entire collection, see Roger Corless, “T'an-luan's Canticles to Amita Buddha," Pure Land 6 (1989): 262-78, and "Tsan A-mi-t'o fo chi (2): Canticles to Amita Buddha," Pure Land 7 (1990): 124-37.
} 
practitioner with pious words to recite during worship, and thus a means for him or her to gain merit.

As we have seen in the early medieval period, there was a blurry line between the various types of gāthās. Whether a verse was extracted from the narrative of a scripture, from the summary of a scripture, or newly composed to summarize a scripture was not always clear. By the late Sui and early Tang dynasties, vernacular Buddhist poetry began to emerge as its own subtradition and was quickly added on to the spectrum of translation-summary-original composition. ${ }^{66}$ Independently circulating ga $\bar{a} t h \bar{a}$ collections of all varieties existed. It is in the context of these kinds of $g \bar{a} t h \bar{a}$ collections that we ought to consider the rise of vernacular Buddhist poetry in the late Sui and early Tang dynasties. Normally, these poems are associated with the names of semi-legendary figures, such as Fu Dashi 傅大士 ("Mahāsattva Fu," 497-569), Pang Yun 龐蘊 (also known as Pang Jushi 龐居士 or "Layman Pang," 740-803), Hanshan 寒山 (“Cold Mountain," seventh cent.?), and Wang Fanzhi 王梵志 (“Brahmacārin Wang," seventh cent.?). It is best not to search for a single figure behind each of these names, as their biographies blur the line between fact and myth, and at least two of their collections show stratification. ${ }^{67}$ Whether or not these works are the

66) Some commentators, such as Jizang 吉藏 (549-623), attempted to make a hard distinction between "integrated gāthās" (tongji 通偈) and “independent gāthās" (bieji 別偈), for which see his Subcommentary on the Hundred-verse Treatise (Bailun shu 百論疏) in T1827: 42.238b. However, given the nature of texts like Fasheng's Hrdaya (discussed above) and Fu Dashi's 傅大士 hymns on the Diamond Sütrā (discussed below), I believe it is better to conceive of these as the two ends of a spectrum.

67) On Fu Dashi, see Zhang Zikai 張子開, Fu Dashi yanjiu (xiuding zengbuben) 傅大士研 究（修訂增補本）(Shanghai: Shanghai renmin chubanshe, 2012). On Pang Yun, see Ruth Fuller Sasaki, Iriya Yoshitaka, and Dana R. Fraser, A Man of Zen: The Recorded Sayings of Layman P'ang (New York: Weatherhill, 1971); and Tan Wei 譚偉, Pang Jushiyanjiu 龐居士研究 (Chengdu: Sichuan minzu chubanshe, 2002). There are strong similarities, for example, between the biography of Pang Yun, the ideal lay Buddhist, and that of Vimalakirti, the archetype of the lay Buddhist supporter (Sasaki, A Man ofZen, 24-25). On stratification in the Hanshan corpus, see Edwin G. Pulleyblank, "Linguistic Evidence for the Date of Han Shan," in Studies in Chinese Poetry, ed. Ronald C. Miao (San Francisco: Chinese Materials Center, 1978), 163-95, which analyzes the end-rhymes of all the Hanshan poems in order to demonstrate that there are at least two distinct bodies of Hanshan poems, one from the Sui or early Tang and one from the late Tang. Paul Rouzer has reviewed the main evidence for the compilation of the Hanshan corpus, as well as several scholarly approaches to it, in On Cold Mountain, 41-50. A good overview of various Chinese, Japanese, and French scholars' opin- 
remnants of a consciously Buddhist "school" of vernacular poetry is impossible to determine, given the lack of evidence. ${ }^{68}$ In any case, they seem to be the first pieces to blur the line between $g \bar{a} t h \bar{a}$ and poetry, sometimes considered the one, sometimes the other. A three-fascicle collection of verse attributed to Pang Yun, for example, was known as Pang Yun's Poetic Gāthās 龐蒕詩偈. ${ }^{69}$ And while Hanshan's collection is referred to as "poetry" in the Xin Tangshu catalogue, we also find Shide 拾得, Hanshan's legendary companion, protesting the fact that people refer to their work as gāthās in the lines I used for my epigraph: "My poetry is also poetry / Though some call them gāthās” 我詩也是詩, 有 人喚作偈. ${ }^{70}$ This, of course, reveals an anxiety over the term "poetry" (shi). As I tried to make clear in the introduction, the word "poetry" carries a level of prestige, and the $g \bar{a} t h \bar{a}$, as something that may or may not be poetry, is a threat of impurity. It is precisely for this reason that the Qing dynasty editors of the Quan Tangshi and Quan Tangwen chose not to include $g \bar{a} t h \bar{a}$ s in their pages. The imperial preface to the latter says, "We have excluded all Buddhist gāthās, Daoist spells, and the like in order to cut off the flow of harmfulness, in order to rectify men's

\footnotetext{
ions on Wang Fanzhi can be found in Xiang Chu 項楚, Dunhuang shige daolun 敦煌詩歌 導論 (Chengdu: Ba-Shu shushe, 2001), 273-81. Xiang Chu himself believes that the majority of poems can be attributed to someone who lived in the Sui and early Tang (the "original" Wang), but that later poets wrote imitation pieces under his name. Iriya Yoshitaka, Paul Demiéville, and Charles Hartman have all opted for a multiple-authors theory, similar to that proposed by Pulleyblank for the Hanshan corpus. See Iriya Yoshitaka 人矢義高, “Ō Bonshi ni tsuite” 王梵志について, Chūgoku bungakuhō 中国文学報 3 (1955): 50-60 and 4 (1956): 19-56; Paul Demiéville, L'œeuvre de Wang le Zélateur (Wang Fan-tche), suivi des Instructions domestiques de l'aïeul (T'ai-kong kia-kiao): poèmes populaires des T'ang (VIIIe-Xe siècles) (Paris: Collège de France, Institut des hautes études chinoises, 1982); and Charles Hartman, "Wang Fan-chih," in The Indiana Companion to Traditional Chinese Literature (Bloomington: Indiana Univ. Press, 1986), 862-63.

68) Xiang Chu proposes the existence of just such a school in "Tangdai de baihua shipai" 唐代的白話詩派, Jiangxi shehui kexue 江西社會科學 2004.2: 36-41. His main piece of external evidence is a remark by the mid-Tang monk Zongmi 宗密 (780-841) that Wang Fanzhi and Fu Dashi belong to the same "category" 類 ("Tangdai de baihua shipai," 41). I am skeptical of this theory, and opt to see these poems as the result of the general spread of vernacularization in literature brought about by Buddhism in the medieval period.

69) See Xin Tangshu 新唐書 (Beijing: Zhonghua shuju, 1975), 519.1530.

70) In the early tenth century, the poet-monk Qiji also refers to Hanshan's poems as gāthās. See his “Ask-Not Poems, at Zhugong (3 of 15)" 渚宮莫問詩一十五首（其三） in QTS 842.9511.
} 
hearts” 至釋道之章咒偈頌等類, 全行刪去, 以防流粉, 以正人心. ${ }^{71}$ When gāthās are considered poetry, they may undermine the very truths poetry is supposed to serve..$^{72}$

Among these vernacular Buddhist poems, we can find a range of styles and functions, corresponding to a greater or lesser degree with contemporaneous standards of poetry. In the Wang Fanzhi corpus, which is actually at least three distinct collections, we find a large number of poems of admonishment, intended to pass on instructions to a younger generation. Though Wang's verses are never labeled "gāthās" in the Dunhuang manuscripts, the one-fascicle collection of his verses contains ninety-two didactic pieces encouraging its audience to filial piety, respect for Buddhist precepts (e.g., against eating meat and drinking alcohol), and hospitality to monks and other guests-topics which often fall under the label of $g \bar{a} t h \bar{a} .{ }^{73}$ Just one example will give the reader a taste of the proverbial flavor of these works.

$\begin{array}{ll}\text { 黃金未是寶 } & \text { Gold is not a treasure, } \\ \text { 學問勝珍珠 } & \text { Scholarship is better than pearls. } \\ \text { 丈夫無伎藝 } & \text { A man who has no skills } \\ \text { 虛霑一世人 } & \text { Tries in vain to influence his contemporaries. }{ }^{74}\end{array}$

Most of the verses of the one-fascicle edition of Wang Fanzhi's works are like this: in terms of content, they actually have very little that is specifi-

\footnotetext{
71) QTW, 2-3.

72) This editorial choice, of course, reflects attitudes of literati about a millennium after the Tang, but is nevertheless worth reflecting on. By excluding gāthās from the imperially commissioned prose and poetry compilations, the editors are saying very clearly that $g \bar{a}$ thās should not even be considered part of normative civilization (wen 文). This retrospective secularization of the Chinese cultural tradition would eventually be picked up as part of China's modernization myth in the late nineteenth and early twentieth century, tying all but the most elite forms of Buddhism and other Chinese religions to the idea of "superstition" (mixin 迷信) and directly influencing modern scholarship on traditional China. For more on this secularization narrative, see Rebecca Nedostup, Superstitious Regimes: Religion and the Politics of Chinese Modernity (Cambridge, Mass.: Harvard Univ. Asia Center, 2009).

73) For example, Chuanchu's 傳楚 (mid-1oth cent.) verse against eating meat is titled “The Patriarch of Qingfeng Mountain's Gāthā on the Prohibition of Meat” 青峰山祖戒肉偈 in the Dunhuang manuscript Stein 2165. For an overview of Wang Fanzhi's one-fascicle collection, see Xiang Chu, Dunhuang shige daolun, 303-306. Demiéville calls this version the "Volume sans numéro (SN)" (L'ouvre de Wang le Zélateur, 326-423).

74) Xiang Chu, Wang Fanzhi shi jiaozhu 王梵志詩校注 (Shanghai: Shanghai guji chubanshe, 1991), 4.483-84; Demiéville, L’ouvre de Wang le Zélateur, 359.
} 
cally Buddhist in them. They are instructional proverbs. In this, we can note a similarity with the sixth-century "Gāthās in Praise of Amitābha Buddha." Both verses are mainly functional, intended to be put to use in a communal setting for the sake of some goal (praise of the Buddha, transmission of instructions, and underlying both, the formation and preservation of a community). What aesthetic factors exist seem to be in the service of this goal.

At the other end of the aesthetic spectrum is the semi-legendary eighth-century lay devotee Pang Yun. His collection of 191 pieces (154 pentameter, 24 heptameter, 13 mixed-meter) display a strong speaker, full of first-person pronouns and seemingly personal thoughts on time, history, reclusion, religious devotion, and Buddhist philosophy. Here is one of his more striking poems, on the theme of emptiness:

無有報龐大 No one gives me enormous rewards,

空空無處坐 Empty empty, nowhere to sit.

家內空空空 In my house, empty empty empty.

4 空空無有貨 Empty empty, with no valuables.

日在空裏行 When the sun's there, I walk, empty within.

日沒空裏臥 When the sun's set, I sleep, empty within.

空坐空吟詩 Empty I sit, empty I chant poems.

8 詩空空相和 Poems are empty, and empty their responses.

莫怪純用空 Don't think it strange that I use only “empty."

空是諸佛座 Emptiness is the seat of the Buddhas.

世人不別寶 Worldly men won't part from their treasures,

12 空即是實貨 But emptiness is itself the treasure,

若嫌無有空 And if you dislike the emptiness of having nothing,

自是諸佛過 $\quad$ Know that $]$ this is the buddhas' pass. ${ }^{75}$

This piece is on a Buddhist theme and clearly has a moral to teach its audience. The phrase "empty empty" (kongkong 空空) is, in fact, a technical term. The famous commentary to the Mahäprajñāpa aramitāsütra, the Da zhidu lun 大智度論, defines it as "when all dharmas are empty, and this emptiness itself is empty" 一切法空, 是空亦空. ${ }^{76}$

75) QTSBB, 20.951; Tan Wei, Pang Jushi yanjiu, 437-38.

76) T1509:25.393c16-17 (attrib. Nagārjuna, trans. Kumārajīva 鳩摩羅什). In the Mahāprajñ̄apāramitā-sūtra 大般若波羅蜜多經 itself, it is listed as the third of twenty varieties of emptiness. See T220: 5.13b (trans. Xuanzang 玄焋 in 660-663). 
Though I have translated this term in lines 2 and 4 as "empty empty" in order to emphasize its striking repetition, it could be rendered with more philosophical precision as "the emptiness of emptiness" - the linguistic concept of emptiness is itself metaphysically empty. Likewise with the kongkongkong of line 3: it refers to a second metadiscursive level, that "the emptiness of emptiness" is also metaphysically empty. The game could be extended ad infinitum. On a literary level, this repetition of kong underscores the main theme of the poem, which is to play emptiness's philosophical meanings (emptiness of individuation and emptiness of language) against its mundane meaning (lack of physical possessions). The speaker's lack of wealth is ironically justified by the philosophical grandeur of the concept of emptiness.

There is also a great deal of craftsmanship on display here. The poem rhymes on line 1 and all even lines $\left({ }^{*}-a H\right)$. We find one instance of clear parallelism (lines 5-6), which also contains an odd word choice for the sake of euphony. The sun is "there" (zai 在) rather than "out" (chu 出), I suspect, because of the assonance between zai and its parallel character $m o$ 沒 in Middle Chinese ( ${ }^{*} d z o j X$ and $\left.{ }^{*} m w o t\right)$. The first line contains a pun on Pang Yun's surname, which literally means "enormous," reminding this reader of the punning self-references abundant in the poetry of John Donne and William Shakespeare. The speaker also self-consciously repeats the character kong over and over again, referring to this very feature in line 9. In line 3, the character is repeated three times for the sake of emphasis - a phenomenon I have called "retriplication" elsewhere, a poetic technique used far more frequently by monks and other poets with strong ties to Buddhism. If we read across the line break, the character appears five times in a row, which we might deem "repentaplication."

What this poem lacks, however, is any sort of regulation of tones according to the rules of meter. We should not be surprised at this, given the vernacular, informal air of Pang Yun's verse, and the fact that they are considered gāthās more than poetry (note that, in the title of his collection, shi 詩 comes first, modifying the main word $j i$ 偈). Nearly all of Pang Yun's poetic gāthās contain no trace of tonal regulation. In my own investigations, I have found only seven pieces that seem to be exceptions. All seven of these were later included in the Southern Song collection Tangshi jishi 唐詩紀事 (Recorded Occasions of Tang Poetry) under 
the label of "poetry" rather than "poetic gāthās." Th These were also the only seven works of Pang Yun included in Quan Tang shi. Thus, we have a clear example of how the ambiguity between "poems" and "gāthās" of the eighth century was later sorted out and fixed into separate categories by the Song and Qing. The roots of this clear division lie in the late Tang.

\section{Gäthā as the Basis for Community}

One of the main functions of $g \bar{a} t h \bar{a}$ s, especially as we enter the late Tang period, is to help constitute and ensure the survival of a community, be that a small group of monks and lay devotees or a lineage spanning centuries. The first of these, contemporaneous monks who practice together, is powerfully illustrated in a narrative preserved in a Dunhuang document, Pelliot chinois $3409 .{ }^{78}$ The beginning of the manuscript, which is damaged, introduces the residents of Mt. Fiveshade (Wuyinshan 五蔭山): Yuanchen 遠塵, Ligou 離垢, Guangzhao 廣照, Jingying 淨影, Zhiji 智積, Yuanming 圓明, and their unnamed disciples. After lighting incense and sweeping the lecture hall clean, each of the monks recites a gāthā. Once they have concluded, and night has fallen, the monks decide to recite "The Five Turns of the Night Watch" (wugeng zhuan 五更轉) and a gātha, after which we pick up the narrative:

The disciples received explanations of the gāthās from the meditation masters, as well as the "Five Turns of the Night Watch" and the "Exhortation to Goodness." The disciples loved the meditation masters and did not know what they could do to detain the meditation masters to live together with them and cultivate the Way. Each of them contemplated, and each composed a piece on "Traveling the Road is Hard."

弟子蒙禪師等說偈, 兼與《五更轉》及《勸善文》。弟子等慈慕禪師。不知為 計留得禪師。共住修循道。各自思維, 各作《行路難》一首。

[The texts of the poems follow.]

77) See Tangshi jishi jiaojian 唐詩紀事校箋, annot. Wang Zhongyong 王仲鏞 (Beijing: Zhonghua shuju, 2007), 49.1327; and QTS 810.9136-37.

78) For a catalogue description, see Michel Soymié, ed., Catalogue des manuscrits chinois de Touen-houang (Fonds Pelliot chinois), vol. 3. (Paris: Fondation Singer-Polignac, 1983), 334-35. 
The six masters, wishing to part, thought it over. But they loved their disciples, so they changed their minds, deciding to dwell together and cultivate the Way. In all, there were thirteen: one they honored as virtuous who served as master, two close to him who were entrusted with duties, and ten who held other positions and begged for food. The monks then intoned "Pacifying the Mind Is Hard."

六師捨得, 尋思一遍, 卻愛慕弟子, 即自迴心共住修道。總共十三人, 尊一個 有德為師, 兩個親近承事, 十個諸方乞食。和上即歎安心難。

[The text of the poem follows.]

Though this narrative is most likely fictional, it represented a meaningful ideal to Tang Buddhists. The gāthās and the other poems recited create the community, since the monks and the disciples share the goal of "cultivating the Way" at Mt. Fiveshade, and they very literally draw the community back together as it threatens to disperse. The disciples, having heard verses recited by their masters, recite verses back at them and thereby convince them to stay. Most importantly, the sense of community is reinforced by the verses' literary features: the gāthās of various monks follow the same structure, and the "Traveling the Road is Hard" songs share the same refrain despite their different meters. The formal harmony of the texts reflects the social harmony of the community. This narrative can provide us with a useful allegory of the role of the gāthā in medieval China: the gāth $\bar{a}$, as a shared textual resource and communally experienced performance, pulls religious devotees together and tries to keep them there. If all is successful, they will stick together and, like the monks at the end of the tale, go on to create more gāthās. The writing of these verses creates a virtuous circle.

The community-building function of $g \bar{a} t h \bar{a}$ s is most conspicuous in the subgenre of dharma-transmission gāthās (chuanfa ji 傳法偈). A dharma-transmission gāth $\bar{a}$ is the embodiment of a master's teachings, a demonstration of his understanding of the true dharma, accompanied by instructions to his disciples to uphold it. The first text to list a series of dharma-transmitting gāthās, so far as we know, is the Dunhuang copy of the Platform Sütra of the Sixth Patriarch 六祖壇經 (S.5475). ${ }^{79}$ In this

79) See Mizuno Kōgen 水野弘元, “Denbōge no seiritsu ni tsuite” 傳法偈の成立について, Shügaku kenkyū 宗學研究 2 (1960): 22-41; Ishii Shūdō 石井修道, “Denbōge no seiritsu no haikei ni kansuru ichi kōsatsu” 伝法偈の成立の背景に関する一考察, Shūgaku kenkyū 22 (1980): 199-205; and Ishii Shūdō, "Denbōge" 伝法偈, in Tonkō butten to Zen 敦煌仏典 
text, which dates to roughly $781,{ }^{80}$ Huineng declares that with an understanding of these verses, there is no need to pass on the robe that symbolizes the transmission of the dharma. So instead he recites the gāthās of each of the six patriarchs (including himself), each verse comprised of four lines of five characters. ${ }^{81}$ These verses delineate a community across time. A lineage, like a genealogy, by its very nature asserts continuity between the living and the dead, including people who had no direct contact with one another. Bodhidharma describes how "from one flower blooms five petals" 一花開五葉. Whether one reads the "five petals" as referring to the next five patriarchs of Chan or its five later schools, the point remains that the metaphor accounts for fundamental similarity across differences. The other five dharma-transmission gāthās of the Platform Sütra reinforce this by developing this same metaphor of natural growth, stressing the importance of different parts-seeds (original Buddha-nature), ground (the mind), rain (the Dharma), flowers (the Samgha), and fruit (enlightenment). A look at the rhymes further solidifies this sense of continuity. The first patriarch Bodhidharma's verse introduces the rhyme with qing 清 (MC: tshjeng) and cheng 成 (MC: dzyeng). Patriarchs 2-5 then employ a slanted rhyme, using only sheng 生 (MC: sraeng) in all rhyme positions, which has a slightly different medial vowel. ${ }^{82}$ The sixth patriarch Huineng, the star of this sütra, is the one who unites the two, using sheng as his first rhyme word and cheng as his second. That is, his first rhyme word demonstrates his continuity with his immediate predecessors, while his second one connects him

\footnotetext{
と禅, ed. Shinohara Hisao 篠原寿雄 and Tanaka Ryōshō 田中良昭 (Tokyo: Daitō shuppansha, 1980), 283-85.

80) The Dunhuang manuscript we have today was likely copied sometime between 830 and 860 based on an 820 edition, but much of its material probably dates back to a few decades earlier. See Philip B. Yampolsky, The Platform Sūtra of the Sixth Patriarch: The Text of the Tun-huang Manuscript with Translation, Introduction, and Notes (New York: Columbia Univ. Press, 1967), 90, 98. See John Jorgensen, Inventing Hui-neng, The Sixth Patriarch: Hagiography and Biography in Early Ch'an (Brill: Leiden, 2005), 595-640, for an overview of various theories of the Platform Sütra's development.

81) For translations of these $g \bar{a} t h \bar{a}$ s and the narrative context in which they appear, see Yampolsky, The Platform Sütra, 176-78.

82) In both the Qieyun 切韻 (comp. 6o1) and Guangyun 廣韻 (comp. 1008) rhyme books, the former two fall under the heading of qing 清, the latter under the heading of $g$ eng 庚. These two categories were extremely close, and many writers did not observe a strict distinction between them.
} 
more directly to his most orthodox precursor Bodhidharma, the originator of Chan in China. Huineng unslants the rhyme, restoring a full resonance with the first patriarch.

The next place we see this genre of dharma-transmission gāthās is the Baolin zhuan 寶林傳 (Transmission of Baolin temple). Probably compiled in $801,{ }^{83}$ it does the Platform Sütra one better, providing dharma-transmission gäthās for the whole line of twenty-eight Indian patriarchs as well as the historical Buddha, Sākyamuni himself. ${ }^{84}$ The first seven, from the Buddha to the sixth Indian patriarch Mikkaka 彌遮迦, are doctrinal statements. Śākyamuni's, for example, reads:

$\begin{array}{lll}\text { 法本法無法 } & \text { The dharma at the root of dharma is no-dharma, } & \text { pjop } \\ \text { 無法法亦法 } & \text { The dharma of no-dharma is also a dharma. } & \text { pjop } \\ \text { 今付無法時 } & \text { Now you are attached to no-dharma: } & \text { dzyi } \\ \text { 法法何曾法 } & \text { How can all dharmas be dharmic? } & \text { pjop }\end{array}$

While this paradox on the insubstantiality of nature (and the substantiality of that insubstantiality) is difficult conceptually, it is simple linguistically. Half of the verse's twenty characters are fa 法, or "dharma," which also functions as the rhyme word. The following six gāthās are similar: they employ simple language to describe paradoxes of the ontological status of dharmas, the mind, language, naming, and the problem of attachment. They use only the very basic, dead metaphors of "awakening” ( $w u$ 寤), “reaching” (tongda 通達), and “freeing” (jie 解), and employ fa (MC: pjop) as their only rhyme word. Vasumitra 婆須蜜, the seventh Indian patriarch, marks a turning point: the key concept of

83) The specific date 801 is not associated with the Baolin zhuan until several centuries later, when it is provided in a Japanese catalogue of 1270; however, the manuscript is listed among the catalogues of texts brought back by Ennin 圓仁 (794-864) from 839 and 847 (see T2165: 55.1075c; T2166: 55.1077c; and T2167: 55.1086c). Unfortunately, fascicles 7, 9, and 10 of the Baolin zhuan are no longer extant. For a further discussion of the authorship, dating, and formation of the Baolin zhuan, see Jorgensen, Inventing Hui-neng, 644-51; Yanagida Seizan 柳田聖山, Shoki zenshū shisho no kenkyū 初期禅宗史書の研究 (Kyoto: Hōzōkan, 1967), vol. 6, 351-65; and Jia Jinhua 賈晉華, “Baolin zhuan zhuzhe ji bianzhuan mudi kaoshu” 《寶 林傳》著者及編撰目的考述, Wenxian 文献 2011.2: 131-39.

84) For the text of all thirty-six of these gäthās compared with versions of them in the Tanfan yize 壇法儀則 and Zutang ji 祖堂集, see Ishii Shūdō, "Denbōge," 293-305. For a good edition of the Baolin zhuan, throughout which the gāthās are distributed, see the Japanese translation of Tanaka Ryōshō 田中良昭, Hōrindenyakuchū 宝林伝訳注 (Tokyo: Naiyama shoten, 2003). 
"emptiness" (xukong 虛空) is introduced, and his successor, Buddhanandi 佛陀難提, begins to employ more complicated language, introducing terms and metaphors not seen in the previous gāthās:

虛空有內外 Emptiness has an inside and outside,

心法亦如此 And consciousness is like this, too.

tshjeX

若了虛空故

If you understand the basis of emptiness,

是達真如理 You will reach the principle of true thusness.

liX

Emptiness is conceptualized both spatially and temporally: it has an inside and outside, it can be reached, and it has a cause ( $g u$ 故)- something that precedes it and gives rise to it. It is here, too, that we finally find a shift in the rhymes. ${ }^{85} \mathrm{In}$ the first eight $g \bar{a} t h \bar{a}$ s, there had been only one rhyme word, $f a$ 法 (MC: *pjop). Beginning with Buddhanandi, a new rhyme is established $\left({ }^{*}-i X\right)$, which will serve as the main rhyme for the next nine patriarchs' verses. ${ }^{86}$ Again, this creates a sense of continuity - and thus the preservation of orthodoxy—across many generations. With Gayāśata 伽耶舍多, the eighteenth patriarch, a new technique is introduced: rather than simply follow the rhymes of his predecessors, his verse employs a kind of anadiplosis (dingzhen 頂針) in which the main rhyme of the previous poem's last line is repeated in the next poem as the final character of the first line. In addition to creating an aural connection which mirrors the doctrinal, this technique helps preserve the order of the stanzas. It is easier to remember that Gayāśața follows Samghanandi 僧伽難提 if their rhymes link up in this way. ${ }^{87}$ And it is with these verses, too, that the extended metaphor of vegetal growth emerges—seeds (zhong 種), flower ( $h u a$ 花), fruit (guo 果), ground ( $d i$ 地), and sprouts (meng 萌) are introduced for the first time. These are the same images and rhymes used in the Chinese Chan patriarchs' dharma-transmission gāthās in the Baolin zhuan. If we look at both the

85) For a list of the rhyme scheme of all thirty extant dharma-transmission gāthās in the Baolin zhuan, see the Appendix.

86) It is clear that the author(s) of these stanzas, like most poets of the late Tang, understand the final vowels $-i$ and $-e$ to be an acceptable cross-rhyme. Unlike others, however, the author(s) also establish rhymes between rising tones (shangsheng 上聲) and departing tones (qusheng 去聲). See, e.g., verses 9, 16, and 26 in the Appendix.

87) This same technique is used to connect verses 23 and 24 (Haklena 鶴勒 and Ārasiṃha 師子), for which see the Appendix. 
rhymes and imagery, it appears that the author(s) of these verses wish to connect Samghanandi and Gayāśața most tightly to the Chinese Chan patriarchs.

Thus gāthās served to build communities in the present and across time by virtue not only of their content, but also of their poetic features. The dharma-transmission gāthās of the Baolin zhuan and the Platform Sütra use rhyme to link a lineage across generations, while the refrains and forms of the monks of Mt. Fiveshade use poetic unity to express social unity. In all of these, the gāthās must resemble poetry to work. It is their literary qualities above all that create bonds between people and characters who might otherwise have very little in common. Verse-of the kind that has regular line length, rhyme, and metaphors that grow and blossom over generations-is the very substance of which their communities are made.

\section{Gāthā Collections in the Ninth and Tenth Centuries}

As we progress into later periods of the Tang dynasty, gāthās show an increasing tendency to follow the rules of regulated verse, a phenomenon some have called the "poeticization" (shihua 詩化) of the gāthā.88 A Dunhuang manuscript of the ninth century, Stein 5692 , vividly illustrates this (Figure 1). ${ }^{89}$ The manuscript contains a long series of poems called "Songs of a Mountain Monk" (Shanseng ge 山僧歌), in sixty-four lines, followed by two eight-line pieces, each introduced with the phrase "another gāthä" (you yiji 又一偈). Both of these gāthās make ironic reference to the "Songs of a Mountain Monk" and to each other. They contradict each other, providing a dual vision like companion pieces in William Blake's Songs of Innocence and Songs of Experience. A close look at their structure, tonal patterns, and rhymes reveals their similarity to poetry. ${ }^{90}$

\footnotetext{
88) Cf. Tan Zhaowen, Chanyue shihun, 7-15; Saitō Takanobu also discusses this phenomenon in Kango Butten, 525-56.

89) For a brief entry on this manuscript, see Lionel Giles, Descriptive Catalogue of the Chinese Manuscripts from Tunhuang in the British Museum (London: Trustees of the British Museum, 1957), 195 .

90) Level tones are represented as empty circles, oblique tones as filled-in.
} 


\begin{tabular}{|c|c|c|c|}
\hline Chinese & Translation & Tones & Rhymes \\
\hline 又一偈 & Another Gāthāa: & & \\
\hline 要得離三塗 & Want to free yourself of the three mires? ${ }^{91}$ & $\bullet \bullet \circ \circ$ & $d u$ \\
\hline 先須認本殊 & First, recognize they're basically different. & $\circ \circ \bullet \bullet$ & $d z y u$ \\
\hline 自來無體面 & They've never had essential features: & $\bullet \circ \circ \bullet$ & mjien $H$ \\
\hline 莫遣使驅驅 & Don't pursue them, or you'll rush after them. & $\bullet \bullet \circ \circ$ & khju \\
\hline 遇我憑君鞄 & If you meet the self, you'd die to rely on another, & $\bullet \bullet \circ \bullet$ & sret \\
\hline 逢人但併除 & If you see the person, you must get rid of it. & $\circ \circ \bullet \bullet$ & drjoH \\
\hline 記取山僧語 & Note well the mountain monk's sayings, & $\bullet \bullet \circ \bullet$ & ngjoH \\
\hline 只此是真如 & For these are true thusness. & $\bullet \bullet \bullet \bullet$ & nyoH \\
\hline 又一偈 & Another Gāthā: & & \\
\hline 非佛非三塗 & There are no buddhas, no three mires, & $\circ \bullet \circ \circ \circ$ & $d u$ \\
\hline 非假亦非殊 & No provisions, and no differentiations. & $\circ \bullet \bullet \circ$ & $d z y u$ \\
\hline 本來無體性 & Originally without essential nature, & $\bullet \circ \circ \bullet \bullet$ & sjieng $H$ \\
\hline 何所有驅驅 & What could one rush after? & $\bullet \bullet \circ \circ$ & khju \\
\hline 有我隨他繁 & If there's a self, you'd die by following others; & $\bullet \bullet \circ \bullet$ & sret \\
\hline 亦不除 & If there's no person, you cannot get rid of it. & ००•• & drjoH \\
\hline 山僧若流語 & If a mountain monk has offered sayings, & $\circ \circ \bullet \circ \bullet$ & ngjoH \\
\hline 卻自忘真如 & He must've forgotten true thusness. ${ }^{92}$ & $\bullet \bullet \bullet \bullet$ & nyoH \\
\hline
\end{tabular}

The gāthās are delicately balanced against each other, embodying the paradoxes of Mahayanist soteriology and ontology. Both claim to represent true thusness (or "suchness," Skt. tattva), the ultimate reality that underlies all phenomena. The "three mires" are the three evil destinies one wants to avoid in rebirth, and it was a truism that one must take refuge in the Buddha and realize the truth of no-self in order to be saved from such malicious fates. The first $g \bar{a} t h \bar{a}$ embodies this mundane truth by emphasizing the original purity of the self. Realization only comes with an authentic encounter with one's true "self" or "person"-no one else can achieve liberation for you (lines $5^{-6}$ ). The second gāthā takes the logic of the doctrines of emptiness and no-self to their extreme, eroding the very idea of an authentic person. Thus, in the end, it contradicts the assertions of the first $g \bar{a} t h \bar{a}$.

91) I.e., the three evil destinies, usually understood to be animals 畜生, hungry ghosts 餓鬼, and hell denizens 地獄.

92) See Quan Dunhuang shi 全敦煌詩, comp. and annot. Zhang Xihou 張錫厚 (Beijing: Zuojia chubanshe, 2006), 15: 6802-04. 
The gāthās' formal features reinforce this point. Using all the same end words (except in line 3), the two act as response poems to each other. ${ }^{93}$ Moreover, with eight lines apiece and a general attempt at tonal balance, they are clearly influenced by the standards of lüsh $i$ 律詩 (regulated verse). Their tonal alteration is not perfect: line 7 of the second verse has two level tones in its even positions, and couplet 4 of poem 1 and couplet 1 of poem 2 do not demonstrate tonal mirroring. But the fact that lines generally feature tonal alteration, and that the middle couplets of both gāthās - the most crucial in regulated verse-follow the prosodic rules of regulated verse, betrays an attempt at poeticization. This fact is even more striking if we contrast the two gāthās with the "Songs of a Mountain Monk" which precede it. Of those songs' sixtyfour lines, fourteen have only six characters (albeit with a strong caesura in the middle, thus being rhythmically equivalent to a 7 -character line). The remaining fifty lines of heptameter do not appear to follow any consistent tonal regulation. ${ }^{94}$ The section labeled "songs" do not follow any of the rules of regulated verse, but the pieces labeled "gāthās" do. For at least one ninth-century writer, gāthās must follow a fixed meter, while songs do not. That is to say, gāthās are supposed to look like poetry, poetry of the highest order.

The tendency of ninth- and tenth-century gāthās to adhere to the rules of tonal prosody remains strong when we look at other gāthā collections. One Dunhuang manuscript preserved in the British Library, Stein 4105 , brings together on an eight-foot scroll some fifty-one gāthās extracted from a variety of sources, from early sūtras to the verses attributed to Fu Dashi 傅大師. ${ }^{95}$ It is hard to date this manuscript, since

\footnotetext{
93) This was a common practice for trying to convey the truths of Buddhism from both mundane and ultimate perspectives. For example, the famous verses of Shenxiu 神秀 and Huineng 惠能 in the Platform Sūtra should be read as complementary, not antithetical. On this point, John McRae, "The Story of Early Ch'an," in Zen: Tradition and Transition, ed. Kenneth Kraft (New York: Grove Press, 1988), 126-30.

94) The songs do, in fact, show a tendency toward regular alteration, but there are enough "mistakes" that lead me to believe this may be more of a force of habit or an intuitive sense of euphony than a conscious effort at tonal patterning.

95) For a catalogue description, see Giles, A Descriptive Catalogue, 195. This manuscript has not been digitized for the International Dunhuang Project nor reproduced in the fourteenvolume Ying cang Dunhuang wenxian: Hanwen fojing yiwai bufen 英藏敦煌文獻：漢文佛 經以外部分, ed. Zhongguo shehui kexueyuan lishi yanjiusuo 中國社會科學院歷史研
} 


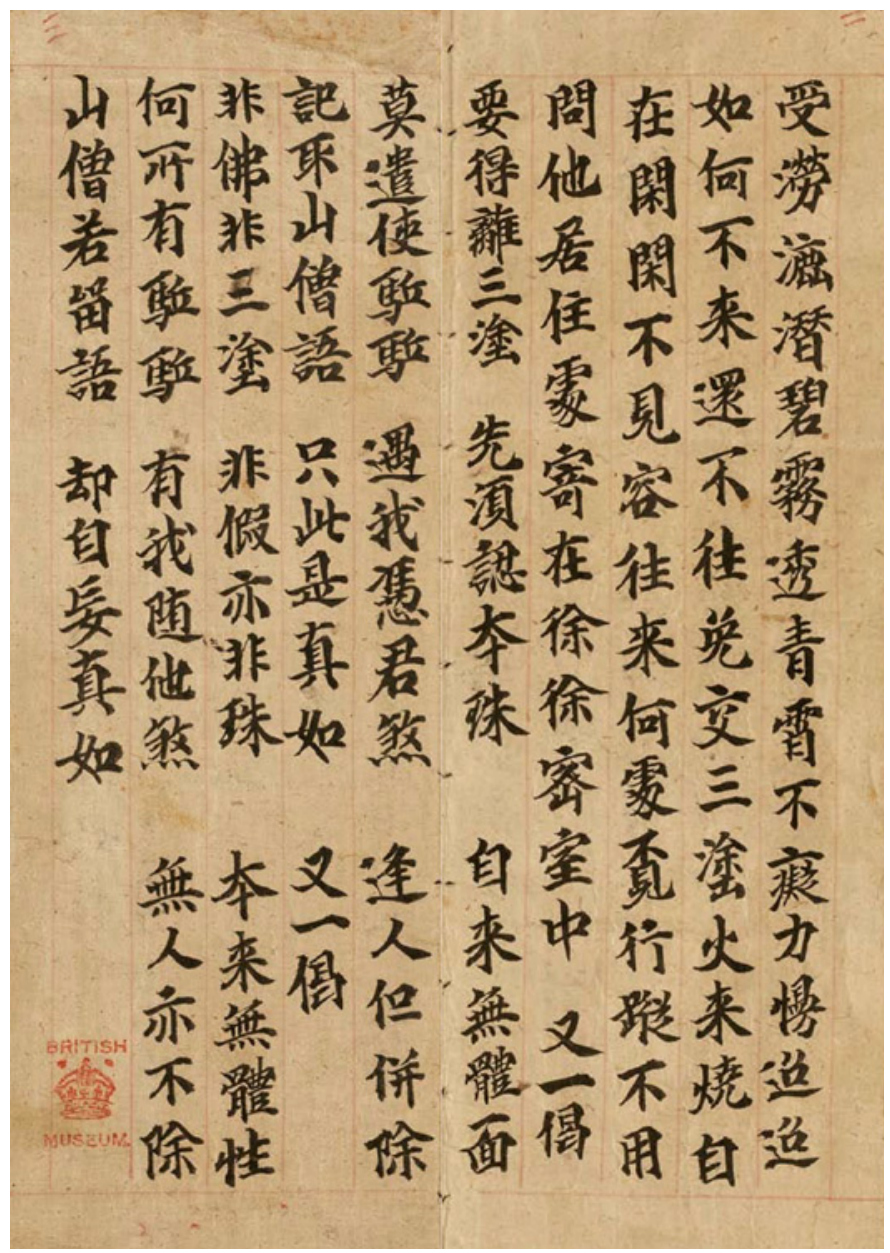

Figure 1: Excerpt from Stein 5692 (British Library, London).

the beginning is damaged and since there is no colophon, but it was likely compiled sometime in the late ninth or early tenth centuries. ${ }^{96}$

究所 (Chengdu: Sichuan renmin chubanshe, 1990-95). My thanks to Susan Whitfield and Mélodie Doumy of the British Library for letting me see the original manuscript.

96) This manuscript is an important source of Fu Dashi's hymns on the Diamond Sūtra and has been studied in that context. Zhang Zikai dates the composition of these hymns to 822831 , but S.4105 by no means belongs to the first generation of copies. See Zhang Zikai, $F u$ Dashiyanjiu, 226. 
Such gāthā collections had circulated since at least the fourth century, but what is surprising about this one is the regularity of the verses: each is comprised of eight lines of pentameter, and each rhymes on all even lines. ${ }^{97}$ Though these verses were composed in a wide variety of times and places, they are all brought together in an anthology under the label song 頌, which, as we have seen, can be a translation of gāthā. One verse in the collection is the gāthā from the Middle-length Sütra of Past Events translated by Kang Mengxiang and Zhu Dali which we examined earlier. Another is a work from Fu Dashi's Diamond Sütra hymns which praises the upholding of a four-line gāthä, something, as we have seen earlier, that contains all the numinous power of a sütra.

Hymn for the Upholding of a Four-line Gātha 頌受持四句偈 $^{98}$

\begin{tabular}{|c|c|c|c|}
\hline 經中四句偈 & A four-line $g \bar{a} t h \bar{a}$ in a sūtra & ००・• & gjet \\
\hline 應知不離身 & $\begin{array}{l}\text { Should be understood, never leaving one's } \\
\text { person. }{ }^{99}\end{array}$ & $\bullet \circ \circ \bullet \circ$ & syin \\
\hline 迷人看似妄 & Deluded people see them as lies, & $\circ \circ \bullet \bullet$ & mjang $H$ \\
\hline 乃唯真 & But the wise as the only truth. & $\bullet \bullet \circ \circ$ & tsyin \\
\hline 法性非因里 & $\begin{array}{l}\text { Dharma-nature is not [subject to] cause and } \\
\text { effect: }\end{array}$ & & $k w a X$ \\
\hline 1 & Appropriately, it is neither old nor new. & $\circ \circ \circ \bullet \circ$ & $\sin$ \\
\hline 空无實 & $\begin{array}{l}\text { The aggregates are empty, without any real } \\
\text { dharmas, }\end{array}$ & $\bullet \circ \circ \bullet \bullet$ & pjop \\
\hline & So how can there be an empty person? & $\circ \bullet \bullet \circ$ & nyin \\
\hline
\end{tabular}

The content of this verse reinforces what we have seen earlier, the power of a sūtra as contained in even its shortest meaningful excerpt. The gāthä's truth-about the emptiness of all phenomena (lines

\footnotetext{
97) These gāthās are labeled with the translated term song (hymn, encomium), not the transliterated $j i$, but it is clear that gāthā is meant. A few of the gāthās miss one end-rhyme, but the fact that these exceptions rhyme in the three other positions means that they were still structured by rhyme.

98) For a modern, typeset version, see Quan Dunhuang shi, 9: 100.4139-40. Other versions of this verse can be found in several other Dunhuang manuscripts, namely S.1846, P.2039, P.3325, and P.3373, as well as T2732: 85.4c.

99) In S.4105, the characters buli 不離 (never leaving) are erroneously inverted, which a later scribe has corrected with a check mark $\left({ }^{\vee}\right)$. For more on the varieties of medieval punctuation marks, see Imre Galambos, "Correction Marks in the Dunhuang Manuscripts," in Studies in Chinese Manuscripts: From the Warring States Period to the 2oth Century, ed. Galambos (Budapest: ELTE Institute of East Asian Studies, 2013), 191-210.
} 
7-8) — transcends time (line 6) and is known only to the wise (lines 3-4). It is a truth which gives one access to incredible power. There is also a recursive logic here: Fu Dashi's gāthä-hymns ${ }^{100}$ are pithy synopses of the Diamond Sütra, which itself extols the power of brief verse synopses of its content. This is a $g \bar{a} t h \bar{a}$ summarizing a scripture which praises a $g \bar{a} t h \bar{a}$ as a powerful summary of that same scripture.

But more importantly for our purposes is the meter of the verse. With the exception of the first line (which reverses the expected tonal patterns), it follows the rules of tonal prosody, alternating the tones of characters within the individual line, within the couplet, and within the quatrain. In fact, the entire manuscript shows a tendency toward tonal regulation, a tendency stronger at lower levels and weaker at higher ones. Nearly all lines alternate tonal classes in their second and fourth characters, and a vast majority of couplets alternate tonal classes across their lines, while at the level of the quatrain and octave the tonal patterning begins to break down. Nevertheless, we see in this manuscript a proclivity for the standard Tang meters. In most manuscript variants between the verses as they appear in $\mathbf{S . 4 1 0 5}$ and the verses as they appear in versions integrated with the text of the Diamond Sütra, the main differences are in end rhymes and metrically significant positions, with S.4105 showing greater regularity. ${ }^{101}$ That is to say, when the verses circulate independently of the scripture, they look more like poems. For example, in the first of Fu Dashi's verses preserved in S.4105, the opening couplet reads:

\footnotetext{
施門通六行 The teaching of giving suffuses the six practices,

六度束三檀 And the six perfections are tied to the three dānas.
} $\circ \circ \circ \bullet \circ$

In this version, the couplet uses synonyms to vary word choice and observe the requirements of tonal meter. "Giving" (shi 施) is a translation of dāna (tan 檀), and the "six practices" (liuxing 六行) are precisely

100) Fu Dashi's verses have been called both gāthās and hymns. Zhu'an 竹庵 (1092-1182), for example, refers to them as gāthās in his remarks recorded in the True Lineage of the Buddhists (Shimen zhengtong 釋門正統), j. 8, in Z1513: 75.350c.

101) For the Taishō edition of The Diamond Sütra with Hymns by Fu Dashi of the Liang Dynasty 梁朝傅大士頌金剛經, see T2732: 85.2a-8c; for the Dunhuang manuscript version on which this is based, see Stein 1846, which Giles dates to the ninth century. 
the same as the "six perfections" (liudu 六度), namely giving (dāna), morality (śila), forbearance (kṣānti), zeal (vìrya), contemplation (dhyāna), and wisdom (prajñā). In the Taishō version of this couplet, the "six perfections" (liudu) are replaced by a repetition of "six practices" (liuxing). While this does not change the meaning of these lines in any way, it ruins the meter: "perfection" (MC: $d u H$ ) has the contrasting oblique tone that satisfies the metrical requirements while "practice" (MC: haeng) does not. ${ }^{102}$ Examples of many other such variations could be given. The effect is that the version embedded in the Diamond Sütra, without as many metrical niceties, would have appeared to be rougher but probably more archaic. Stein 4105 , on the other hand, would have sounded better for oral recitation in the late medieval period, and it was this version that was collected with other gāthās and copied more frequently than others. ${ }^{103}$ That is to say, compilers more often used the metrically regular versions for independently circulating gātha collections and the archaic versions for weaving into the Diamond Sütra.

In the early tenth-century collection The Gāthās of the Reverend of Longya 龍牙和尚偈頌, written by Judun 居遁, the majority of its ninetyfive verses are comprised of four lines of regulated heptameter. The gāthās clearly serve a didactic purpose, instructing the reader/listener in how to become a practitioner. The first six stanzas, for example, all begin with the phrase "When studying the Way" (xue dao 學道) and then pass on specific principles. The second $g \bar{a} t h \bar{a}$ reads:

\section{學道先須且學貧 When studying the Way, one must first study poverty. \\ 學貧貧後道方親 Study poverty, then once you're poor the Way will be near. \\ 一朝體得成貧道 Once you strive for it with your body, you will achieve the Way of poverty.}

4 道用還如貧底人
When this Way is used, you will return as if a poor and lowly person. ${ }^{104}$

102) There are fifteen Dunhuang editions of Fu Dashi's verses, many of which circulated independently of the text of the Diamond Sütra, including Pelliot chinois 2039, 2629, 4823; Stein 4732, 3373; and Dx 201. For an overview of Dunhuang manuscript versions of these verses, see Zhang Zikai, Fu Dashi yanjiu, 193-213.

103) Zhang Zikai calls S.4105 the "parent" (muben 母本) of later copies (Fu Dashiyanjiu, 199). 104) Z1298: 66.726. 
The contrast between this gāthā and Pang Yun's verse on emptiness and poverty is illuminating. Whereas Pang Yun employs witty self-references, Judun offers plain instructions for his disciples. They were probably meant to be memorized and practiced at various points in one's monastic training. ${ }^{105}$ There is very little "poetry" here, if by that we mean vivid imagery, elaborate wordplay, or a strong personal voice. The fact that these lines show perfect tonal regulation and rhyme on lines 1, 2, and 4 (which match the expectations of what "poetry" should look like at the time) is to be explained by the fact that such features aid the process of memorization and by the community-building and -preserving function of $g \bar{a} t h \bar{a}$ s (as seen in Pelliot chinois 3409 and the Baolin zhuan). For very practical reasons, these $g \bar{a} t h \bar{a}$ s take on the appearance of poetry. Thus, it is difficult to tell the two genres apart at first glance.

The preface to this ga $\bar{a} t h \bar{a}$ collection, written by the prolific poet-monk Qiji 齊已 (ca. 864-938) is worth quoting, since it provides further evidence for the fuzziness of the border between gātha and poem in the tenth century. We shall look at it in more detail below, but for now, let us note just one particularly interesting sentence: "Though in form [gāthās] are the same as poetry, their aims are not poetic” 雖體同於詩, 嫄旨非 詩也. ${ }^{106}$ Poetry and gāthās look the same, but they try to do different things. Gāthās are distinct from poetry not necessarily because they treat Buddhist themes, but because they have a different purpose: whereas poetry makes claims to aestheticism and authenticity, ${ }^{107} g \bar{a} t h \bar{a} \mathrm{~s}$ are used in rituals and in the transmission of the Dharma. Any similarity is at the level of the surface, says Qiji. However, the very fact that he feels the need to make this distinction means that people were confusing the two. Gāthās were, at least to the unsophisticated, poetry. It seems that the average, literate man of tenth-century China did have a concept of

105) In this, Judun follows the admonitory nature of early gāthās associated with Chan lineages. See Tanaka Ryōshō 田中良昭, “Shūdōge I” 修道偈 I, in Tonkō butten to Zen, 245-62. A portion of Judun's other gāthās, like those of other monks associated with southern lineages, are more philosophical in nature, reflecting on the concept of emptiness. Such verses are still didactic, even if not directly admonitory.

106) Z1298: 66.726.

107) By this, I refer to the whole shiyan zhi 詩言志 ("poetry bespeaks what is intently on the mind") discourse, which dominates traditional Chinese poetics as strongly as Aristotle does Western poetics. For an introduction to these texts, see the translations and commentaries in Stephen Owen, Readings in Chinese Literary Thought, 26-29. 
"religious poetry." Poetry and gāthās were, at least formally, impossible to tell apart. It was only by referring to extra-textual phenomena, such as the function of a piece in a given community or the identity of the author, that one could clearly separate the two terms.

\section{The Image of Gāthās in Ninth- and Tenth-century Poetry}

The danger of the blurred line between poetry and $g \bar{a} t h \bar{a}$ s is even more apparent when we turn to representations of the gātha in poetry from this period. In the following poem, written by Xu Tang 許棠 (b. 822, jinshi 871$)^{108}$ to the poet-monk Qibai 棲白 (fl. 851), we find the terms "gāthās" and "poems" set in parallel to one another, essentially equating the two.

“Given to the Venerable Qibai” 贈棲白上人

$\mathrm{Xu}$ Tang 許棠

閑身卻不閑 Relaxing body, but not relaxed.

日日對天顏 Day after day, setting face to heaven.

已住城中寺 Having lived in a temple in the city,

4 難歸海上山 It's hard to go back to a mountain by the sea.

詩傳華夏外 Your poems travel beyond China,

偈布市朝間 Your gāthās spread over the markets and courts.

欲問空門事 I want to ask about the Gate of Emptiness:

8 空門豈有關 How can the Gate of Emptiness be barred?109

The poem is excellent occasional poetry, and like many such poems is written in perfect regulated meter. It sets out a noble image of its subject as a monk striving to religious purity, expresses regret at their separation, then praises his fame inside and outside of the Tang empire, and concludes with a winking reference to Buddhist doctrine. On a literal level, it should be impossible to bar an "empty gate" (lines 7-8). But the "Gate of Emptiness" 空門 here has a double meaning: it is both the literal door to Qibai's residence which Xu Tang is frustrated to find shut

108) A degree he apparently attained with much difficulty: one anecdote tells us that he sat for the exam over twenty times! See Taiping guangji 太平廣記, comp. Li Fang 李昉 (925996) (Beijing: Zhonghua shuju, 1961), 183.1363.

109) QTS 603.6971. 
(playing on the trope of not finding a recluse one is searching for $)^{110}$ and also the teachings on emptiness (Buddhism) which Xu Tang must access through the monk Qibai. For our purposes, the most important lines are $5^{-6}$, which implicitly equate poems with gāthās. The middle two couplets of regulated verse are supposed to adhere to strict parallelism, and Xu Tang achieves this beautifully, matching every word of the two lines, character by character. In fact, the parallelism is so expertly achieved that it overrides fact. There is no evidence that Qibai ever wrote anything called a gāthā. His collection of verse, now no longer extant but mentioned in the Song imperial catalogue, is simply titled Qibai's Poetry Collection, in One Fascicle 棲白詩集一卷. ${ }^{111}$ None of his nineteen extant poems are labeled gāthās. ${ }^{112}$ It seems that Xu Tang was simply looking for a near-synonym for "poems," and, because he was writing a poem for a monk, and monks are Buddhists, and gāthās are Buddhist verse, he chose the word "gāthä" to fill in the blank.

But one need not be a monk to write a gāthā. A poem can be labeled a gāth $\bar{a}$ even if the author is a literatus, as long as the poet is associating himself with a monk and writing on Buddhist themes. Along these lines, we find two gāthās attributed to Sikong Tu 司空圖 (837-908).

\author{
“Two Gāthās with Elder Funiu” 與伏牛長老偈二首 \\ Sikong Tu 司空圖 \\ 其一 I \\ 不算菩提與闡提 Don't consider bodhi \\ to be given to icchantikas, ${ }^{113}$
}

110) On this trope, see Paula Varsano, "Looking for the Recluse and Not Finding Him In: The Rhetoric of Silence in Early Chinese Poetry," Asia Major 3rd ser. 12.2 (1999): 39-70.

111) See Song shi 宋史 (Beijing: Zhonghua shuju, 1980), 208.5386.

112) He has sixteen poems in QTS and three in QTSBB. Of course, it may be that Qibai did write $g \bar{a}$ thās and these were simply lost in transmission. But, given that Qibai was a prominent monk based in the capital whose exchange poetry circulated as far as Dunhuang (see P.3386) and who was closely associated with such famed poets as Jia Dao 賈島 (779-834), Yao He 姚合 (775?-855?), Li Pin 李頻 (d. 876), Guanxiu, and Qiji (on these last two, see below), it is just as likely that he did not write anything that would be called a gāthā.

113) Bodhi means enlightenment. In Yogacāra philosophy, icchantika is a category of sentient beings incapable of attaining enlightenment. It can also be used more generally to refer to bad Buddhist practitioners. Cf. Seishi Karashima, "Who Were the Icchantikas?" Annual Report of the International Research Institute for Advanced Buddhology (2007): 67-80, which claims that the term originally referred to conservative monks and gradually became a term of disparagement. 


\begin{tabular}{|c|c|c|}
\hline & 惟應執著便生迷 & $\begin{array}{l}\text { With their clinging they only } \\
\text { produce further confusion.114 }\end{array}$ \\
\hline & 無端指個清凉地 & $\begin{array}{l}\text { Causelessness points to } \\
\text { a cool, clear ground__ } 115\end{array}$ \\
\hline 4 & 凍殺胡僧雪嶺西 & $\begin{array}{l}\text { Foreign monks freeze to death } \\
\text { west of the Snow Peaks. }{ }^{116}\end{array}$ \\
\hline & 其二 & II \\
\hline & 長繩不見系空虛 & $\begin{array}{l}\text { Long ropes cannot be } \\
\text { tied to emptiness, }\end{array}$ \\
\hline & 半偈傳心亦未疏 & $\begin{array}{l}\text { The half-ga } \bar{a} t h \bar{a} \text { transmits the mind, } \\
\text { and it is undifferentiated. }{ }^{117}\end{array}$ \\
\hline & 推倒我山無一事 & $\begin{array}{l}\text { To topple our mountain } \\
\text { is nothing at all: }\end{array}$ \\
\hline 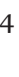 & 莫將文字縛真如 & $\begin{array}{l}\text { Don't use words } \\
\text { to bind up true thusness. }{ }^{118}\end{array}$ \\
\hline
\end{tabular}

The title of the poem is ambiguous: did Sikong Tu co-write these poems with Funiu, did he write them after conversations with the monk, or did he simply give these poems to the monk ( $y u$ 與 construed as a full verb)? With no preface, it's impossible to tell. In any case, the strong association with the monk seems to merit calling these two pieces gäthās. ${ }^{119}$ It should also be noted that, in terms of form, both are perfect examples of jueju 絕句 in seven-character meter. The content of these verses, much like the content of Sikong Tu's poems on poetics, are a disjunctive array of allusions, philosophical language, and vivid imagery - what Owen calls "the poetics of Oz." 120 Sikong Tu appears to be aware of this, as he begins the first gāth $\bar{a}$ by correcting the reader's potential misunderstanding of the relationship between two transliterated Sanskrit terms. These verses are only comprehensible with a strong knowledge of

\footnotetext{
114) “Clinging” (zhizhu 執著) here refers to tanhā (Skt. trṣnāa, literally “thirst"), the concept which underlay the Second Noble Truth that clinging or attachment is the root of suffering. 115) "Cool, clear ground": the originally pure self.

116) "Snow Peaks" refers to the Himalaya Mountains, the name of which literally means "Snow House" in Sanskrit.

117) The half-gāthā, of course, refers to the story of Buddha and Indra mentioned earlier in this paper.

118) QTS 633.7266.

119) There are gāthās attributed to other lay poets, such as Bai Juyi 白居易 (772-846).

120) Owen, Readings in Classical Chinese Literary Thought, 301.
} 
insider Buddhist terminology: the icchantikas as unenlightenable beings (who therefore lack bodhi), the image of the original self as a "cool, clear ground," and the story of the Buddha's desire to hear the second part of the half-gātha . But when these allusions are put together, it becomes a compressed articulation of the Mahāyāna doctrine of no-self. In this way, the condensed, nearly fragmentary style of the gāthās enacts the difficulty of Buddhist doctrine and practice. It attempts to move the reader to perform the concluding line: to get beyond language, to not let mere words tie down our sense of reality to the mundane.

$G \bar{a} t h \bar{a}$ s, then, were strongly associated with Buddhist monks, and we find mention of them in many poems written for monks. At one level, this is obvious: they entered China as markedly Buddhist forms of verse and that connection to the religion never ceased. At another level, we may wonder why Tang poets, especially late Tang poets, felt compelled to write about monks and temples in the language of Buddhist discourse. That is, why did Tang poets need to use insiders' terminology to describe a religious tradition to which they normally positioned themselves as outsiders? It seems that, like the rhetoricians of the classical West, they thought that the language should match the subject. This phenomenon is best described by a phrase coined by Li Dong (d. late ninth cent.), in his poem “Given to Master Sanhui” 贈三惠大師: “stitching together gāthās" (zhuiji 経偈), a phrase that has the added benefit of rhyming in Tang Chinese ("trwjet gjet). ${ }^{121}$ Poets writing on "Buddhist" topics, such as monks and temples, patched together various Buddhist phrases and allusions, often making no real attempt at integrating them into a seamless unity. An extreme case of stitching together gāthās is a poem by Zhang Pin (jinshi 895).

121) QTS 723.8295. The original line describes the monk's activities: "In the shadows of the medicine tree, always stitching together gāthās” 藥樹影中頻綴偈. The medicine tree is a common metaphor for the dharma, since both are potent healing agents. See, e.g., the Mahāprajñāpāramitā-sūtra, T220: 7.941a, 956b; the Prajñāpāramitā-sūtra of the Surpassing Heavenly King (Shengtianwang banruo boluomi jing 勝天王般若波羅蜜經, trans. Yueposhouna 月婆首那 [Upaśūnya?] in 565), T231: 8.705a, 719c; Avataṃsaka-sūtra (Huayan jing 華嚴經, trans. Buddhabhadra 佛駄跋陀羅 c. 420), T278: 9.501c-502a, 777a; the Mahāparinirvāna sūtra, T374: 12.429a, 553a; etc. 
“To Master Lingyin of Faqian Temple” 寄法乾寺令諲太師 122 Zhang Pin 張䗰

師居中禁寺

You live in a forbidden temple ${ }^{123}$

外請已無緣

With no connection to the outside. ${ }^{124}$

望幸唯修偈

Wishing for favor, alone you put together gāthās.

4 承恩不亂禪

Embracing grace, you don't ruin dhyāna.

院多喧種藥

Your courtyard is filled with clamorous herbs.

池有化生蓮

Your pond has spontaneously born lotuses.

何日龍宮裏

Some day, in the Dragon Palace, ${ }^{125}$

8 相尋借法船

I'll borrow a dharma boat to search for you. ${ }^{126}$

This poem is truly bizarre, as it seems the author had little to no understanding of the Buddhist terminology he was using. To take just one example, of particular interest to this paper, the phrase "put together gāthās" (xiuji 修偈) has an odd ring to it: it appears nowhere in the entire Taishō canon, a collection of some 2,920 texts in eighty-five massive volumes. ${ }^{127}$ There is a bit of a royal theme running through, with the phrases “forbidden temple" 中禁寺 and “Dragon Palace” 龍宮, and the mention of receiving "favor" 幸 and "grace" 恩 from a benefactor, presumably the emperor. Lotuses, ponds, and herbs are all vaguely Buddhist imagery, but there is no depth to these allusions. The "dharma boat" refers to the teaching of the Buddha, which carries people over to nirvāna and is then discarded; it is never something one employs to go searching for another human within the world of samsāra. What we

122) Faqian Temple was located in Chang'an. Its construction in the late 840 s at the command of Emperor Xuānzong 宣宗 (r. 847-870) is described by Zhixuan 知玄 (809-881) in the Fozu tongji 佛祖統紀 (T2035: 49.386c) and the Song Biographies of Eminent Monks (T2061: 50.744a).

123) That is, Zhang Pin is drawing attention to the fact that Lingyin lives in a temple in the capital, near the "forbidden inner [quarters]" (zhongjin 中禁) of the imperial palace.

124) Reading qing 情 for qing 請. I suspect that the author wrote qing 請 (*dzjiengH) in order to have an oblique 厄 tone in this position, as required by the meter (qing 情 is *dzjieng). Wuyuan 無緣 ("no connection") can also be a technical Buddhist term meaning "unconditioned," a sense Zhang Pin fails to capitalize on.

125) That is, the mythical palace of the nāga kings, said to be located beneath the sea. In chapter 12 of the Lotus Sütra, Manjuśri travels there to convert countless beings (T262: 9.35a). 126) QTS 702.8076-77.

127) A database search will return 8 apparent results, but upon closer inspection, in every result the two characters are separated by a punctuation mark. "Ruin dhyanna" 亂禪 is a similarly rare phrase, though it does show up about 30 times throughout the Taishō canon. 
have here is a secular poet playing with Buddhist terminology, but it is poorly digested, reminiscent of the scriptural gāthā of the Han dynasty which simply piled together stock descriptions of the Buddha's physical characteristics. And yet, since it has survived to the present day, it must have worked: Master Lingyin or one of his disciples was pleased enough with the poem to preserve it. The work was accepted as poetry. Verse written to a monk is supposed to make use of Buddhist allusions, something Zhang Pin does in abundance here. These phrases need only make a modicum of sense: Buddhist terminology is used here less as a semantic signifier and more as a discursive marker. Many gāthās written by monks show a similar composition method-"stitching together" Buddhist terms - even if they display a better understanding of what those terms mean. Gāthās of this time tend to be patchwork pieces-the stitching may be more or less skilled, but always it shows.

\section{Guanxiu and Qiji on the Gäthā}

This brings us to two of the most prolific and innovative poets of the period, Guanxiu 貫休 (832-913) and Qiji 齊已 (ca. 864-938). As monks, ${ }^{128}$

128) To date, the best introductions to poet-monks in the ninth and tenth centuries are Wang Xiulin 王秀林, Wan-Tang Wudai shiseng qunti yanjiu 晚唐五代詩僧群體研究 (Beijing: Zhonghua shuju, 2008); Zha Minghao 查明昊, Zhuanxingzhong de Tang Wudai shiseng qunti 转轉型中的唐五代詩僧群體 (Shanghai: Huadong shifan daxue chubanshe, 2008); Sun Changwu 孫昌武, “Tang Wudai de shiseng” 唐五代的詩僧, in Tangdai wenxue yu fojiao 唐代文學與佛教 (Xi'an: Shaanxi renmin chubanshe, 1985), 126-71; and Tan Zhaowen, Chanyue shihun. Some basic information on poet-monks in English can be found in Egan, Clouds Thick, Whereabouts Unknown; and Burton Watson, "Buddhist Poet-Priests of the T'ang," Eastern Buddhist 25.2 (1992): 30-58. As for Guanxiu and Qiji specifically, the interested reader should begin by consulting Edward H. Schafer's encyclopedia entries on them: "Kuanhsiu," in The Indiana Companion to Traditional Chinese Literature (Bloomington: Indiana Univ. Press, 1986), 509-510; and "Ch'i-chi," in The Indiana Companion, 249-51. On Guanxiu, the only substantial works in English are Schafer's "Mineral Imagery in the Paradise Poems of Kuan-hsiu," Asia Major n.s. 10 (1963): 73-102; and my “Guanxiu's 'Mountain-Dwelling Poems': A Translation," Tang Studies 34.1 (2016): 99-124. The fullest treatment of his life and work is still Kobayashi Taichirō 小林太市郎, Zengetsu Daishi no shōgai to geijutsu 禪月大師の生 涯と藝術 (Tokyo: Sōgensha, 1947); the chronology of Guanxiu's life appended to Guanxiu geshixinian jianzhu 貫休歌詩繫年箋注, ed. and annot. Hu Dajun 胡大浚 (Beijing: Zhonghua shuju, 2011), is also a rich resource. To my knowledge, no study focused on Qiji exists in English, French, German, or Japanese. In Chinese, there are only two works devoted exclusively to him, namely Yin Chubin 尹楚涁, “Hu-Xiang shiseng Qiji yu Guiyangzong” 湖湘詩 僧齊已與溈仰宗, Hunan daxue xuebao (shehui kexue ban) 15.4 (2001): 22-27; and Hsiao 
they must have had intimate familiarity with gāthās in the three overlapping senses of the term (as the verse sections of sütras, as a component of efficacious ritual, and as Buddhist verse). How do they conceive of the term gāthā? Do they describe their own poetry with this term, or do they distance themselves from it? Do they use the term at all, and if so, how?

In general, Guanxiu and Qiji seem to resemble their lay contemporaries. Given the fact that they were both deeply embedded in the social world of literate monks, their collections contain hundreds of poems written for other monks. Many of these poems refer to the circulation of gāthās among monks, and between monks and literati:

\footnotetext{
儻為新句偈 If you should make new lines of $g a \bar{t} t h a \bar{s}$,

寄我亦何妨 Send them to me without hesitation.

—Guanxiu, from "Sending a Meditation Monk Back to Minzhong in the Spring" 春送禪師歸閩中129
}

古衣和蘚衲 Your old robes are patched with moss,

新偈幾人傳 Your new gāthās circulate among a few people.

—Guanxiu, from “On Staying at a Meditation Monastery” 題宿禪師院 ${ }^{130}$
百千萬億偈 A hundred thousand myriad million gāthās-
共他勿交涉 He would not associate with others.
—Guanxiu, from "On Hearing that Clergyman Wuxiang Has Passed Away (5 of 5)" 聞無相道人順世五首 (其五) 131

之子之東洛 You are going to Luoyang in the east,

囊中有偈新 In your bag, you have new gāthās.

—Guanxiu, from “Sending off a Monk to the Eastern Metropolis" 送僧之東都132

$\begin{aligned} \text { 道者藥壚留要妙 } & \begin{array}{r}\text { Men of Dao: their medicinal kilns } \\ \text { leave behind essential subtleties; }\end{array}\end{aligned}$

林僧禪偈寄相思 The forest of monks: their meditation $g \bar{a} t h \bar{a} \mathrm{~s}$ are sent off as they think of one another.

—Guanxiu, from “To the Uncle of Yang Gongdu” 贈楊公杜之舅133

\footnotetext{
Li-hua 蕭麗華, “Wan-Tang shiseng Qiji de shichan shijie” 晚唐詩僧齊己的詩禪世界, Foxue yanjiu zhongxin xuebao 佛學研究中心學報 2 (1997): 157-178.

129) QTS 830.9352-53; Guanxiu geshi xinian jianzhu, 9.460-61.

130) QTS 830.9354-55; Guanxiu geshixinian jianzhu, 9.477.

131) QTS 830.9351-52; Guanxiu geshi xinian jianzhu, 9.445-51.

132) QTS 832.9387; Guanxiu geshi xinian jianzhu, 15.705-06.

133) QTS 837.9431-32; Guanxiu geshixinian jianzhu, 24.1029-32.
} 
誰論傳法偈 Who talks about dharma-transmission gāthās?

自補坐禪衣 I mend seated-meditation robes.

—Qiji, from “Sent to a Friend, from Jingmen in Autumn” 荆門秋日寄友人134

身離道士衣裳少 Your body, having departed from Daoist priests, grows thin inside your robes.

筆答禪師句偈多 Your brush responds to meditation masters' many lines of gāthās.

—Qiji, from “Sent to Zheng Gu, Gentleman of the Interior” 寄鄭谷郎中135

To Guanxiu and Qiji, as to their secular contemporaries, gāthās are religious verse (they come in "lines" 句), strongly associated with monks. They circulate within the networks of literate monks, as well as between monks and literati. And they apparently were produced at an astonishing rate: Guanxiu's hyperbolic "hundred thousand myriad million gāthās" and Qiji's image of Zheng Gu dashing off responses to monks while in retirement express the same anxiety of abundance. Monks everywhere were writing gāthās, sending them off to anyone who would read them, and hoping for replies. ${ }^{136}$ To monks who considered themselves serious poets, like Guanxiu and Qiji, this mass-production may have smacked of amateurism and thus was degrading to their own efforts.

134) QTS 843.9535; Qiji shiji jiaozhu 齊已詩集校注, ed. and annot. Wang Xiulin 王秀林 (Beijing: Zhongguo shehui kexue chubanshe, 2011), 6.333.

135) QTS 845.9553; Qiji shiji jiaozhu, 8.415.

136) Any attempt to quantify the amount of $g a \bar{t} t h \bar{s}$ s written in this period quickly runs into a host of problems. For example, the compendium Quan Dunhuang shi divides its contents into three sections, “Poems” 詩歌 (fascicles 1-118), “Song Lyrics 曲詞 (fascicles 119-154), and “Gāthās and Praises” 偈讚 (fascicles 155-194), in which gāthās appear to occupy about $21 \%$ of verses recorded in Dunhuang documents. However, upon closer inspection, many verses which are labeled $g \bar{a} t h \bar{a}$ s in the original manuscripts are classified in other sections, such as the monk Liangjia's 良價 (807-869) “Gāthā on Leaving His Parents” 辭親偈 (Stein 2165), which is placed in the "Poetry" section (7:55.2819-21). Editor Zhang Xihou offers no rationale for such reclassifications. Moreover, Quan Dunhuang shi collates various versions of the same work to produce an idealized critical edition, thus masking the relative quantities of various works and their genres. For example, if a verse was copied onto 100 manuscripts, it would only appear once in Quan Dunhuang shi and would thus not affect the numbers enough to make for a useful means of comparison. Other compendia of Tang literature share similar problems. 
For this reason, Guanxiu and Qiji attempted to distance themselves from the label $g \bar{a} t h \bar{a}$, a term referring to something that's not quite real poetry. Among the over 1,500 extant poems by the two monks, I find only four pieces labeled gāthās (0.26\%), all by Guanxiu, and all of which directly treat Buddhist doctrine. ${ }^{137}$ This is rare for these monks: while their works express a deeply held Buddhist worldview, they rarely approach Buddhist topics by means of a "frontal attack," to use C. S. Lewis's description of one kind of religious poetry. ${ }^{138}$ Instead, it manifests itself in their poems' formal features and allusions. Therefore, Guanxiu and Qiji, though monks themselves, understand what they are doing as the practice of poetry. In this way, they maintain and even attempt to strengthen the boundary between "poems" and "gāthās," aligning themselves with the more prestigious term. They see themselves as poets, not mere $g \bar{a} t h \bar{a}$-scribblers. Thus Guanxiu pays a back-handed compliment to another monk in the following poem.

\section{“Delighted at Venerable Busi's Arrival” 喜不思上人來 Guanxiu 貫休}

沃州那不住

Didn't stay in Wozhou, 139

一別許多時

Left and gone for long.

幾度懷君夜

How many nights I've thought of you,

4 相逢出夢遲 When meeting in dreams, I'm reluctant to part.

瓶擔千丈瀑 Your jar can hold a Thousand-Fathom Waterfall, ${ }^{140}$

偈是七言詩

Your gāthās are 7 -character poems.

137) His “Gāthās on the Nature of the Way" 道情偈, as a single poem (QTS 828.9334; Guanxiu geshixinian jianzhu, 6.329-30) and as a three-poem series (QTS 835.9411; Guanxiu geshi xinian jianzhu, 19.871-74). In QTS 828.9325-26, we also find a hymn of praise to Wang Jian 王建, the King of Shu 蜀 (r. 907-918), by Guanxiu titled "A Gäthā Expressing My Feelings, Presented to Gaozu of the Great Shu on a Qianlong Day” 大蜀高祖潛龍日獻陳情偈頌. But it seems that the original title of this poem was “A Hymn Expressing My Feelings" 陳情頌, since that is how it was referred to in poetry-talks (shihua 詩話) from the tenth century. See Guanxiu geshi xinian jianzhu, 5.248.

138) C. S. Lewis, review of The Oxford Book of Christian Verse, ed. David Cecil, in The Review of English Studies 17 (1941): 99.

139) Wozhou is the name of a mountain in the southeast of Shan county 炏縣 (in today's Zhejiang province, south of the Hangzhou bay).

140) Probably a reference to the waterfall at Thousand-Fathom Peak 千丈岩瀑布, also located in Zhejiang, east of Wozhou. A temple called Xuedou si 雪竇寺 (Snowdrain Temple) had been built near the waterfall during the Jin 晉 $(265-420)$. 


\section{若向羅浮去 If you wish to go to Luofu, ${ }^{141}$ \\ 8 伊余亦願隨 I would hope to follow. ${ }^{142}$}

In the third couplet, the highest compliment Guanxiu can give to Busi is to describe him as a literatus, lavishing extravagant praise on his ability to drink and write poetry. He guzzles beverages at the rate of a waterfall and writes gāthās that are good enough to be considered poetry. By using "poetry" as a term of praise, of course, Guanxiu retains the hierarchy of the two terms: most monks' gāthā are merely verse, but Busi's rise above the rest, even to the point of being considered real works of literature. There is an implicit self-aggrandizement here: whereas Busi is a mere monk who wrote $g \bar{a} t h \bar{a}$ s, which may rise to the level of poetry, Guanxiu is a poet writing real poetry, who just happens to be a monk.

With all this in mind, we can finally turn back to Qiji's preface to Judun's collection of gāthās and look at it in detail. Far from being a straightforward account of the development of the $g \bar{a} t h \bar{a}$, this preface is a finely crafted work of rhetoric, simultaneously achieving two contradictory goals: praising its subject while distancing himself from it.

Regarding the transmission of $g \bar{a} t h \bar{a}$ s within the Chan tradition, from the twentyeight patriarchs [of India] to the six patriarchs [of China], they are no longer extant. But later, venerable monks in various lands composed them as well. ${ }^{143}$ In this way, through their chanting, they were able to penetrate mysterious themes.

Indeed, if not for the study of the supramundane, none would ponder over these famous lines. In the beginning of the Xiantong reign period (Nov. 860-Nov. 874), there were the writings of the two masters of Xinfeng and Baiya, which spread throughout the forests of meditation. Though in form they were the same as poetry $[s h i]$, their aims were not poetic. The deluded looked at them and clapped their hands. Recently, some of Longya's disciples put together a collection of the

141) This probably refers to the Luofu mountains in Xunzhou 循州 (in today's Guangdong province, north of Shenzhen 深圳), for which see Jiu Tangshu 舊唐書 (Beijing: Zhonghua shuju, 1974), 41.1715; not the Mt. Luofu 羅浮山 of Daoist fame, located south of Lake Dongting 洞庭湖 (Shuijing zhushu 水經注疏 [Nanjing: Jiangsu guji chubanshe, 1989], 29.2441-43). For example, Shitou Xiqian 石頭希遷 (710-790), a native of Gaoyao 高要 in Duanzhou 端 州 (west of modern Guangzhou), is said to have taken precepts at the Xunzhou Luofu mountains (see Zutang ji 祖堂集 [Changsha: Yuelu shushe, 1996], 4.89).

142) QTS 831.9369; Guanxiu geshi xinian jianzhu, 20.587.

143) The editors of $Z$ mispunctuate this text, placing a stop after que 厥 instead of wang 亡, in which case the passage would read: "...have come down to us without fail. Later, venerable monks..." I follow Chen Shangjun's reading here. 
master's writings and begged me to write a preface to it. Longya is the inheritor of Xinfeng.

Whenever one entrusts imagery to carry across mystery, it must contain great significance. Just as horse-jaw pearls and mussel embryos burst and dazzle below waves, one tries to pick out their subtle flavors. Only then does one awaken to a spiritual contemplation of stillness, like roaming in an empty expanse. None of this is like the semblance of language. Moreover, it's said that when Confucius met Uncle Warmsnow in Lu, he raised his eyebrows and blinked his eyes to convey the Dao, so what's to stop one from using language? ${ }^{144}$ And so ends this preface. Below are the gāthās, ninety-five in total. ${ }^{145}$

禪門所傳偈頌, 自二十八祖止於六祖, 已降則亡。㷧後諸方老宿亦多為之。蓋 以吟暢玄旨也。非格外之學, 莫將以名句擬議矣。洎咸通初有新豐白崖二大師 所作, 多流散於禪林。雖體同於詩, 劂旨非詩也。迷者見之而為撫掌乎。近有 侾龍牙之門者, 編集師偈乞余序之。龍牙之嗣新豐也。凡託像寄妙必含大意。 猶夫騼領蚌胎炟耀波底, 試捧習味但覺神慮澄蕩, 如遊胗廓, 皆不若文字之狀 矣。且曰魯仲尼與溫伯雪子揚眉瞬目示其道而何妨言語哉。乃為之序云耳。偈 頌凡九十五首。

The preface opens with a short narrative of the development of the $g \bar{a} t h \bar{a}$, in which it is associated with the orthodox transmission of teachings from one Chan patriarch to the next. Despite the fact that the original gāthās of the patriarchs are lost (apparently Qiji had not read Baolin zhuan), later monks kept the true dharma alive through their later compositions. This passage lends dignity and authority to the works of Judun (i.e., Longya), recognizing them as part of a world movement ("later, venerable monks in various lands composed them as well"). Judun is

144) Zhuangzi jishi, 21.706: "When Confucius saw Warmsnow, he did not say a word. Zilu said, 'Master, you have long wanted to see Uncle Warmsnow, but now that you have seen him you didn't say a word. Why?' Confucius said, 'As soon as my eyes came in contact with that man, I felt that I was in the presence of the Dao. There was simply no room for me to make a sound"' (translation lightly modified from Victor H. Mair, Wandering on the Way: Early Taoist Tales and Parables of Chuang Tzu [New York: Bantam Books, 1994], 200). Qiji may have been fond of this allusion because Li Bai 李白 had used it in his poem "Sent to Recluse Wen [=Warm] on His Return to His Old Dwelling Place on White Crane Peak in the Yellow Mountains”送溫處士歸黃山白我鳥峰舊居 (LiBaijijiaozhu李白集校注, annot. Qu Tuiyuan 篗蛻園 and Zhu Jincheng 朱金城 [Shanghai: Shanghai guji chubanshe, 1980], 16.977-80).

145) Z 1298: 66.726. This piece is not included in Qiji shiji jiaozhu. In fact, it was completely ignored by scholars of Tang literature until Chen Shangjun wrote a brief note on it in the mid-gos. See Chen Shangjun 陳尚君, “Qiji yiwen 'Longya heshang jisong xu' kaoshu” 齊已 佚文《龍牙和尚偈頌序》考述, Yiyang shizhuan xuebao 益陽師專學報 15.4 (1994): 76-77. 
then placed within one branch of this movement, that of Xinfeng, which rose to prominence in the early 86os. Gäthās, then, as the distillations of one's teachings, are signs of enlightenment, passed down from master to master. The lineage is intact: even though we may have no direct access to it, the very fact of its existence means that the verses are orthodox. Qijis history of gāthās is a miniature transmission lineage, shoring up the deceased master's authority.

Qiji then praises the profundity of thought in the earlier gāthās, since that is their purpose: one reads gāthās for the teachings, not for any aesthetic experience. As Qiji says, "Indeed, if not for the study of the supramundane, none would ponder over these famous lines." ${ }^{146}$ And it is with this sentence that we start to become suspicious of Qiji's effusive praise for Judun and the gātha form in general. The statement implies that, as works of art, gāthās are useless, unworthy of attention. They are, in short, utilitarian, nothing but vessels to convey teachings from one mind to another. The only people who seem to take any sort of delight in the gāthās are "the deluded" (mizhe 迷者)—a technical Buddhist term, antonym of "the enlightened" (wuzhe 悟者)—who "clap their hands" (fushou 撫手) in response. ${ }^{147}$ While this reaction may seem to indicate

146) Gewai 格外, here translated as "supramundane," literally means “[those things which are] beyond the pattern/structure [of normal reality]" and could also be rendered "extraordinary" or "unusual." Fellow poet-monk Shangyan 尚顏 (830s?-920s?), in a poem flattering Fang Gan 方干 (d. 885?), writes: "Extraordinary, you stitch together pure poems; / Famed in poetry, alone you achieved recognition” 格外緅清詩、詩名獨得知 (“Sent to Recluse Fang Gan” 寄方干處士, in QTS 848.96oo). In a preface to a collection of famous paintings, Zhu Jingyuan 朱景元 (mid-ninth cent.) describes how those who did not fit into any of Zhang Huaiguan's 張懷瓘 (early-eighth cent.) categories as "unusual" (gewai) and "not restrained by norms” 不拘常法 (“Preface to the Record of Famous Painters of the Tang” 唐朝名畫錄 序, in QTW763.7936). In the Buddhist canons (T, Z, and others), gewai is not frequently used until the Song dynasty.

147) One may object that mizhe can also be understood in a neutral-to-positive sense, as "those who are enchanted [with the gāthās]," but a look at the works of Qiji and his contemporaries demonstrates that this reading would be incorrect. Throughout Qiji's corpus, mi 迷 is most frequently used in its literal sense of being physically lost, but in more metaphoric uses it usually carries negative connotations. In one of his poems, Qiji contrasts two kinds of poets: "Accomplished men all follow a single thread; / The deluded are naturally manyforked” 達人皆一貫, 迷者自多岐 (“Speaking of Poetry” 言詩, in QTS 841.9502; Qiji shiji jiaozhu 4.231). In “Spring Flora” 春草, Qiji describes King Fuchai 夫差 of Wu (r. 495-473 BCE) as having "lost" ( $m i$ ) his own state when he led it into utter destruction (QTS 840.9483; Qiji shiji jiaozhu 3.167-68). In “A Split-gut Tortoise” 夸腸龜, Qiji laments the taking of a tortoise's life for the purpose of divination: "If it were capable in spiritual matters, / Its life should be 
childish amusement on the part of the deluded, it actually indicates disdain. In Qiji's "Sent to the Spirit of Zheng Gu in the Western Mountains" 寄西山鄭谷神, probably written in 909, he contrasts Zheng Gu's Buddhist practice with "The vulgar [who] would clap their hands / And chant the Yellow Court Classic in a quiet place” 俗人應撫掌, 閑處誦黃 庭. ${ }^{148}$ Gāthās are something that common people sneer at.

Then comes Qiji's theory of imagery, which, in the context of a preface to a collection of utilitarian, unimaginative gāthās, seems to be dripping with irony. Images are praised as the best vehicle for conveying the deepest truths. They are subtle, like pearls and mussels beneath ocean waves, full of flavor but also hidden from everyday view. Despite the fact that they are wrapped in turbulence (waves, bursting and dazzling), the meaning they convey is that of stillness, silence. The "empty expanse" (liaokuo 翏廓) implies both freedom and void, a higher plane that cannot be comprehended by ordinary thought, requiring instead a "spiritual contemplation" (shenlü 神慮). This truth, he goes on to say, does not resemble mere language in any way. However, the signposts pointing in

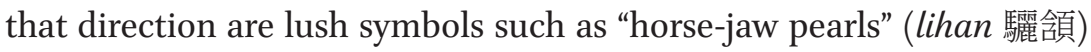

\footnotetext{
long preserved; / If it were capable in omens, / Why should its death be confused (mi)?" 爾既能于靈, 應久存其生, 爾既能于瑞, 胡得迷其死. See QTS 847.9587; Qiji shiji jiaozhu 10.557. In a praise song for his master's recitation of the Lotus Sütra, Xiuya 修雅 (tenth cent.?), writing in a style very similar to that of Qiji and Guanxiu, declares: "The master's name is the king of medicine, and he does the Buddha's commands. / He came to heal all beings' mental illnesses, / He is able to make the deluded (mizhe) clear, / The crazy sane, / The filthy pure, / The crooked straight, / And the mundane sagely" 師名醫王行佛 令, 來與眾生治心病, 能使迷者醒, 狂者定, 垢者淨, 邪者正, 凡者聖. See QTS 825.9298; Tangyin tongqian 唐音統籤, ed. Hu Zhenheng 胡震亨 [1569-1645] (Shanghai: Shanghai guji chubanshe, 2003), 910.17-18. Thus, to understand mizhe here as a neutral-topositive term, meaning "those enchanted [with the gāthās]," would require some audacious acrobatics of interpretation.

148) QTS 842.9506; Qiji shiji jiaozhu 5.238-39. Wang Xiulin, Qiji's modern editor, mistakenly writes "poem" (shi 詩) for “spirit" (shen 神) as the last character in the title. In later Chan yulu 語錄 (recorded sayings) and chuandenglu 傳燈錄 (flame records), clapping one's hands and laughing can be a sign of enlightenment, but this just demonstrates the antinomian character of Song-dynasty Chan, not that clapping was a universal sign of enlightenment. That is to say, the rhetoric of the yulu and chuandenglu is so powerful precisely because it attaches a striking new meaning to such gestures. The Yellow Court Classic (Huangting jing) mentioned in the poem is of course one of the fundamental scriptures of medieval religious Daoism.
} 
and "mussel embryos" (bangtai 蚌胎), imagery so lavish that it lies on the edge of human thought. ${ }^{149}$ The ineffable is reached via aesthetics.

All well and good. This is a coherent literary theory, especially coming from a professional in spiritual matters. The irony emerges from the fact that it is embedded in the preface to a collection of didactic gāthās, which are almost completely barren of imagery. Remember the Judun quatrain quoted earlier:

\begin{tabular}{|c|c|c|}
\hline 學道先須且學貧 & $\begin{array}{l}\text { When studying the Way, one must first } \\
\text { study poverty. }\end{array}$ & $\bullet \circ \circ \bullet \bullet$ \\
\hline 學貧貧後道方親 & $\begin{array}{l}\text { Study poverty, then once you're poor } \\
\text { the realm of the Way will be near. }\end{array}$ & $\bullet \circ \circ \bullet \bullet \circ$ \\
\hline 一朝體得成貧道 & $\begin{array}{l}\text { If you strive for it all morning with your body, } \\
\text { you will achieve the Way of poverty. }\end{array}$ & $\bullet \circ \bullet \bullet \circ \circ \bullet$ \\
\hline 道用還如貧底人 & $\begin{array}{l}\text { When this Way is used, you will return as if } \\
\text { a poor and lowly person. }\end{array}$ & $\bullet \bullet \circ \circ \bullet \circ$ \\
\hline
\end{tabular}

This is an instructional quatrain, stripped of figural language. Its resemblance to poetry, as Qiji states earlier in the preface, is external: its use of rhyme and tonal prosody. Imaginative imagery, that which Qiji regards as the best path by which to approach Mystery, is precisely what is $e x$ cluded from Judun's verse. If we read between the lines, we find that Qiji is undercutting the works he is supposed to be venerating. Moreover, he does it in the kind of rich language eschewed by Judun. Qiji, in short, outshines his colleague.

After this, we reach the preface's conclusion. It alludes to a story from the Zhuangzi in which Confucius meets Uncle Warmsnow 溫伯雪子. When Confucius realizes that the latter so fully embodies the Dao that there is no room for words, he merely raises his brows and blinks his eyes to communicate. This story is about the inadequacy of words, like the farcical episode in chapters 18-21 of François Rabelais's Pantagruel, in which Panurge must debate the theologian Thaumaste entirely with gestures since such non-verbal language is the only way they can

\footnotetext{
149) Also, apparently, it is imagery Qiji considered so good that he used it in one of his own poems. He writes: "The two axles dazzle [like] a mussel embryo and a horse-jaw pearl" 兩軸 蚌胎驪領耀, in “Taking Leave of the Judge of Qin Prefecture, I Send Him the Cinnabar Terrace Collection”謝秦府推官寄丹台集 (QTS 844.9542; Qiji shiji jiaozhu, 7.365-66).

150) $Z$ no. $1298,66: 726$.
} 
properly discuss ineffable truths. The story of Confucius and Uncle Warmsnow is then ironically used to justify the attempt to use words to convey the depths of Buddhist doctrine. If the allusion means anything, it completely undermines the practice of writing gāthās: words cannot convey the greatest of mysteries. Qiji's abrupt halt after the flippant rhetorical question "so what's to stop one from using language?" reinforces this point. The Confucius and Uncle Warmsnow of the Zhuangzi, being sensitive to the nature of Truth, recognize the value of silence; Judun and his followers, apparently, have not learned that lesson. The preface is thus similar to the one written by $\mathrm{Du} \mathrm{Mu}$ 杜牧 (803-852) for Li He's 李 賀 (790-816) poetry collection - a preface that Qiji must have read, since he wrote a poem called “On Reading a Collection of Li He's Songs” 讀李 賀歌集. ${ }^{151}$ The praise is so hyperbolic that it becomes laughable and thus undercuts its own laudatory function. Whereas Du Mu may have recognized in $\mathrm{Li} \mathrm{He}$ the aesthetic realm's challenge to the order of reality, ${ }^{152}$ Qiji finds Longya's verse so bland that he must undermine and contradict it with his own rhetorical flourishes so that it might not stain him. Qiji, essentially, is claiming that he occupies Li He's aesthetic realm, completely divorced from the dry didacticism of Longya's stitched-together gāthās.

\section{Conclusion}

The term gāthā proved to have great elasticity over the 800-year period examined in this essay. From the first $g \bar{a} t h \bar{a}$ s that were simply verses in translated Buddhist scriptures to independently-circulating collections of spells and praise-poems, gāthās in the early medieval period posed no threat to the concept of poetry. Instead, they were mainly valued for the truths they contained, the teachings they conveyed, and their efficacy in ritual. Six Dynasties China associated gāthās more closely with song and zan, genres of verse considered to be on the margins of poetry. In the Sui and early Tang, vernacular Buddhist verse attributed to more or less legendary practitioners began to challenge the neat line dividing

151) See QTS 847.9584-85; Qiji shiji jiaozhu, 10.546-47.

152) See the discussion in Stephen Owen, The Late Tang: Chinese Poetry of the Mid-Ninth Century (827-860) (Cambridge, Mass.: Harvard Univ. Asia Center, 2006), 158-59. 
gāthās from poems. These verses, like many earlier gāthās, primarily served didactic purposes, but many also demonstrated a high level of craftsmanship in form (rhyme and tonal prosody), imagery, and the speaker's voice. Therefore, they variously fell under one label or the other (or both, in the case of Pang Yun). Further into the Tang, monks began to write verse in abundance, which their literati contemporaries often referred to as gāthās. These gāthās were seen as less witty, less important, and less crafted than poems, often "stitched together" out of various Buddhist allusions, images, and doctrines. However, the desire to re-draw a clear line between the two terms means that people were confusing the two, regarding $g \bar{a} t h \bar{a}$ s as a kind of poetry (albeit an inferior one).

The great poet-monks of the late Tang, Guanxiu and Qiji, whom we might expect to be supporters of gāthās, in fact tried to distance themselves from the term. They regarded themselves first and foremost as poets, and they felt that their identity as monks should not interfere with that. Gāthās were the instructional, patchwork pieces composed by their lesser colleagues; their own verse was poetry. When the disciples of the monk Judun begged Qiji, the famous writer who was also a monk, to write a preface to their master's gāthā collection, Qiji obeyed the letter of the request but not the spirit. Rather than writing an introduction that fittingly praised the gāthās' usefulness in practice, he chose to overwhelm the reader with majestic imagery, ironic allusions, and promises of grandeur-promises the collection could not deliver on. In this way, he was able to distance himself from the bland didacticism embodied in Longya's gāthās.

Poetry is a label of prestige, only bestowed on those linguistic acts a culture deems worthy of the term. It is a concept defined through exclusion. The gātha is what's excluded in the Tang, an act of separation that would be reconfirmed in the subsequent centuries. In his entry on "Poetry" in the Princeton Encyclopedia of Poetry and Poetics, Stephen Owen surveys the definition of poetry in a variety of European, Middle Eastern, Indic, and East Asian cultures, concluding that "in each case, a cultural authority of one sort or another can step in and say, 'That is not poetry.' Yet each of the diverse practices of poetry in the early twentyfirst century derives from some moment in the history of the word, and 
each stakes a claim that excludes some practice of poetry elsewhere."153 In the early tenth century, the poet-monks Guanxiu and Qiji were those cultural gatekeepers, so focused on entering the gate themselves that they blocked the way for their lesser colleagues, whose poetry were labeled gāthās. Effectively, they said that "Buddhist verse" ( $g \bar{a} t h \bar{a})$ isn't poetry, only verse by us two Buddhists is poetry. There is, of course, irony in all this, and even a layer of irony beneath that irony. The very form of "poetry" in this period, the use of elaborately patterned meters, owes its genesis to the chanting of gāthās in the late fifth century. The rules underlying regulated verse began as attempts to capture some of the elements of Sanskrit poetics, and it was these rules that came to define the shape of true poetry in the later medieval period. Thus, the $g \bar{a} t h \bar{a}$ is both manifestly excluded from and latently present in the most highly esteemed genre of shi in the Tang.

\section{Appendix: Rhymes of the Baolin zhuan's Dharma-transmission gāthās}

The following is a reconstruction of the rhyme scheme of the Baolin zhuan's dharmatransmission gāthās (chuanfa ji 傳法偈), reading all thirty-six quatrains as if they were stanzas of a single poem. The purpose is to demonstrate the verses' interconnections, especially how repeated rhymes were used to establish continuity across generations. The main rhymes are listed in capital letters. Final characters that do not constitute the main rhyme of its own stanza but rhyme with another stanza's main rhyme are listed in lowercase letters. An asterisk $\left({ }^{*}\right)$ indicates an off-rhyme, defined as rhyme words with the same medial and final but different tones.

o Śākyamuni 釋迦牟尼佛

法本法無法

無法法亦法

今付無法時

法法何曾法

pjop

pjop

$d z y i$

pjop

1 Mahākāśyapa 大迦葉

法法本來法

無法無非法

何於一法中

有法有不法 pjop

pjop

pjop
A

A

i

A

A

A

A

2 Ānanda 阿難

本來付有法 pjop A

付了言無法 pjop A

各各自須浯 $n g u H \quad \mathrm{~g}$

㝥了無無法 pjop A

3 Śānakavāsa 商那和修

非法亦非心 $\operatorname{sim} \mathrm{k}$

非心亦非法 pjop A

說是心法時 $d z y i \quad \mathrm{i}$

是法非心法 pjop A

153) Owen, "Poetry," in Princeton Encyclopedia of Poetry and Poetics, 1068. 
4 Uptagupta 優婆脒多

心自本來心 $\operatorname{sim}$

本心非有法 pjop

有法有本心 $\operatorname{sim}$

非心非本法 pjop

5 Dhṛtaka 提多迦

$\begin{array}{lll}\text { 通達本法心 } & \text { sim } & \mathrm{j} \\ \text { 無法無非法 } & \text { pjop } & \mathrm{A} \\ \text { 嶈了同未寤 } & n g u H & \mathrm{~g} \\ \text { 無心亦無法 } & \text { pjop } & \mathrm{A}\end{array}$

6 Mikkaka 彌遮迦

$\begin{array}{lll}\text { 無心無可得 } & \text { to } & \mathrm{B} \\ \text { 說得不名得 } & \text { tok } & \mathrm{B} \\ \text { 若了心非法 } & \text { pjop } & \mathrm{A} \\ \text { 始解心心法 } & \text { pjop } & \mathrm{A}\end{array}$

7 Vasumitra 婆須蜜

心同虛空界

示同虛空法

証得虛空時

pjop

無是無非法

$d z y i$

pjop

8 Buddhanandi 佛陀難提

虛空有內外

心法亦如此

tshjeX

C

若了虛空故

kuH

是達真如理

liX

g

C

9 Buddhamitra 伏駄蜜多

真理本無名 mjieng

d

因名顯真理

liX

受得真實法

pjop

非真亦非偽

ngjweH

10 Pārśva or Pārśvika 脇

真體自然真

因真說有理 $\quad l i X$

C

領得真真法

pjop

無行亦無止
A

j

A

A
B

A

A

11 Punyayaśas 富那耶舍

迷䓊如隱顯

明暗不相離 $\quad l j e H \quad \mathrm{C}$

今付隱顯法 pjop a

非一亦非二 $n y i j H \quad \mathrm{C}$

12 Aśvaghoṣa 馬鳴

$\begin{array}{lll}\text { 隱顯即本法 } & \text { pjop } & \mathrm{a} \\ \text { 明暗元不二 } & \text { nyijH } & \mathrm{C} \\ \text { 今付㝥了法 } & \text { pjop } & \mathrm{a} \\ \text { 非取亦非棄 } & k h j i j H & \mathrm{C}\end{array}$

13 Kapimala 毗羅

非隱非顯法 pjop a

說是真實際 tsjeH C

寤此隱顯法 pjop a

非愚亦非智 $\quad t r j e H \quad \mathrm{C}$

14 Nāgârjuna 龍樹

為明隱顯法 pjop a

方說解脫理 liX C

於法心不証

無瞋亦無喜 $x i X \quad \mathrm{C}$

15 Kāṇadeva 迦那提婆

本對傳法人

為說解脫理 $\quad l i X$

C

於法實無証

無終復無始 SyiX

C

16 Rāhulata 羅睺羅多

於法實無証

不取亦不離 $\quad \mathrm{jeH} \quad \mathrm{C}^{*}$

法非有無相

內外云何起 khiX C

17 Samghanandi 僧伽難提

心地本無生 sraeng d

因種從緣起 khiX C

緣起不相妨

花果亦復爾 nyeX $\mathrm{C}$ 
18 Gayāśața 伽耶舍多

有種有心地 $d i j H$

因緣能發萌

maeng

於緣不能礙

當生生不生 sraeng

D

19 Kumārata 鳩摩羅多

性上本無生

sraeng

為對求人說

sywet

於法既無得

何懷決無決

kwet

20 Jayata 闍夜多

言下合無生

同於法界性

sraeng d

若能如是解

sjeng $H \quad F$

通達事理竟

kjaengH $\mathrm{F}$

21 Vasubandhu 婆修盤頭

泡幻同無礙

如何不了悟

達法在其中

非今亦非古

$n g u H$

G

$k u X$

G

22 Manorhita 摩拏羅

心逐萬境轉

轉處實能幽

Pjiw

$\mathrm{H}$

隨流認得性

sjieng $H$

無喜復無憂

?juw

$\mathrm{H}$

23 Haklena 鶴勒

認得心性時

可說不思議

dzyi

ngjeH

tok

了了無可得

trje

24 Ārasimhha 師子

正說知見時

$d z y i$

sim

知見俱是心

當心即知見

知見即于今

C

D

d

E

E

d

F

F


154

34 Nanyue Huairang 南岳壞讓 [not extant]
Mazanec

35 Mazu Daoyi 馬祖道一

[not extant] 